\title{
ÆUSGS
}

\section{Estimating Sediment Flux to Jamaica Bay, New York}
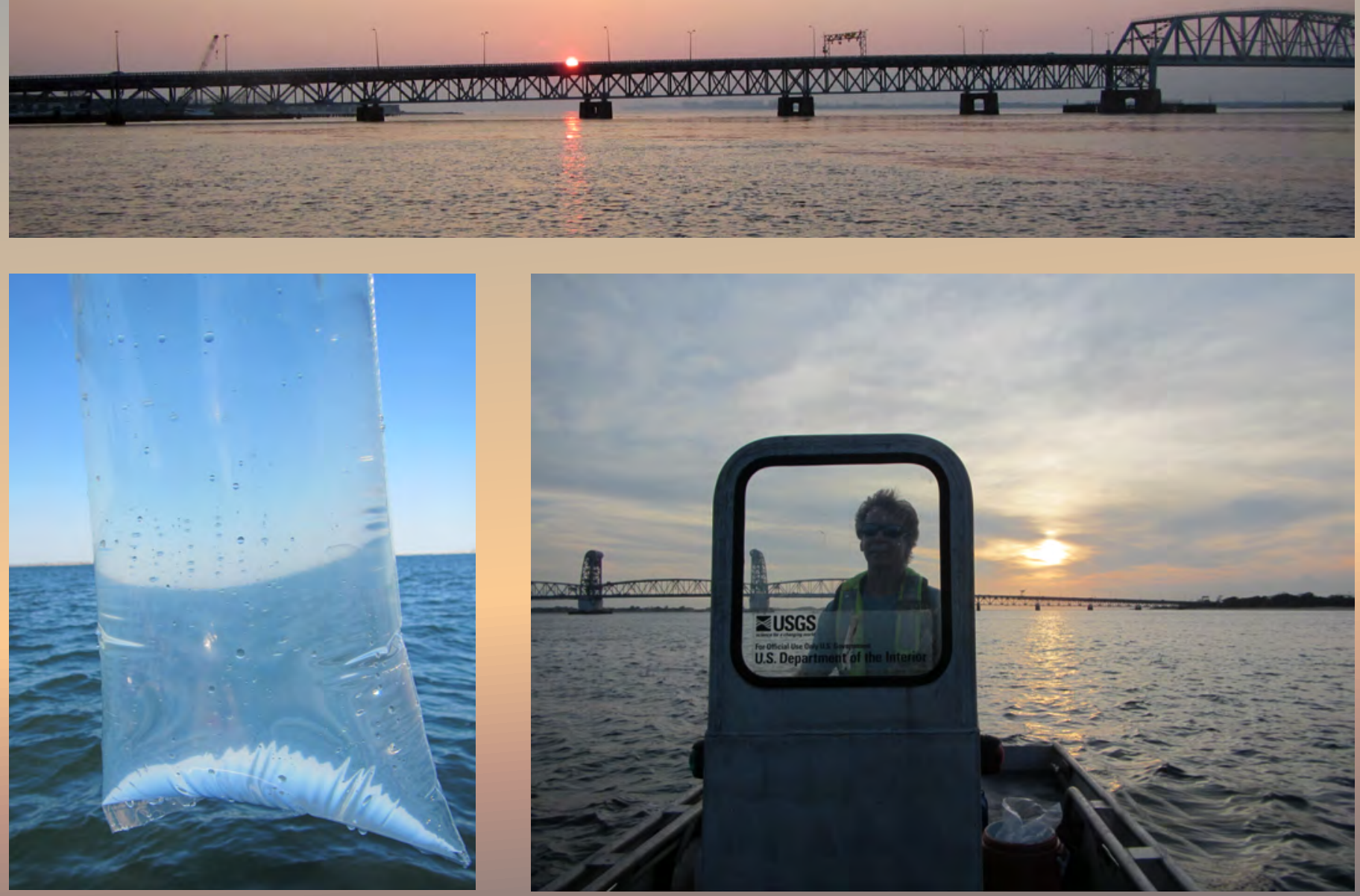

Scientific Investigations Report 2019-5085

U.S. Department of the Interior

U.S. Geological Survey 
Cover. Top: Sunset over Rockaway Inlet, New York, March 2015; photograph by A. Simonson, U.S. Geological Survey. Bottom left: Collecting water samples of suspended-sediment concentration in D-96-A1 sample bag, April 2016; photograph by U.S. Geological Survey. Bottom right: Richard Cartwright navigating through Rockaway Inlet, October 2018; photograph by Natalie Cheung, U.S. Geological Survey. 


\section{Estimating Sediment Flux to Jamaica Bay, New York}

By Richard A. Cartwright and Amy E. Simonson

Scientific Investigations Report 2019-5085 


\title{
U.S. Department of the Interior DAVID BERNHARDT, Secretary
}

\author{
U.S. Geological Survey \\ James F. Reilly II, Director
}

U.S. Geological Survey, Reston, Virginia: 2019

For more information on the USGS - the Federal source for science about the Earth, its natural and living resources, natural hazards, and the environment-visit https://www.usgs.gov or call 1-888-ASK-USGS.

For an overview of USGS information products, including maps, imagery, and publications, visit https://store.usgs.gov.

Any use of trade, firm, or product names is for descriptive purposes only and does not imply endorsement by the U.S. Government.

Although this information product, for the most part, is in the public domain, it also may contain copyrighted materials as noted in the text. Permission to reproduce copyrighted items must be secured from the copyright owner.

Suggested citation:

Cartwright, R.A., and Simonson, A.E., 2019, Estimating sediment flux to Jamaica Bay, New York:

U.S. Geological Survey Scientific Investigations Report 2019-5085, 25 p., https://doi.org/10.3133/sir20195085.

ISSN 2328-0328 (online) 


\section{Acknowledgments}

This study was part of the Estuarine Physical Response to Storms project (GS2-2D), supported by the Department of the Interior Hurricane Sandy Recovery program. The authors thank the New York Metropolitan Transportation Authority Bridges and Tunnels for granting permission to install monitoring equipment at the site and for efforts to coordinate access and safety issues at the site.

The authors thank the members of the U.S. Geological Survey (USGS) New Jersey Water Science Center and Woods Hole Coastal and Marine Science Center for their technical support in site design and field sampling. Additional analytical support of sediment sampling protocol was provided by Aimee Downs, USGS Kentucky Sediment Laboratory. Field and analytical support were provided by Riley Behrens, Natalie Cheung, Kaitlyn Colella, Jason Finkelstein, Christopher Schubert, Tristen Tagliaferri, and Gary Wall, all of the USGS. 



\section{Contents}

Acknowledgments ……...................................................................................................................

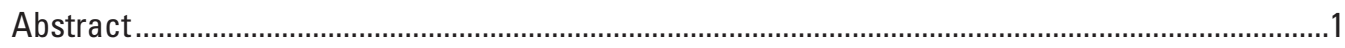

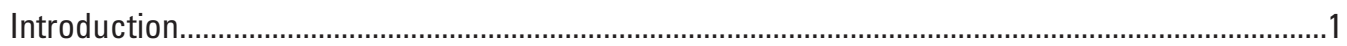

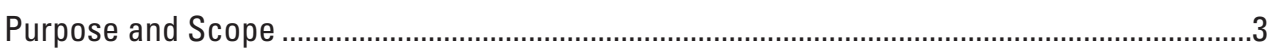

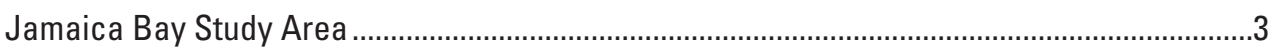

Methods of Data Collection and Analysis ……….................................................................

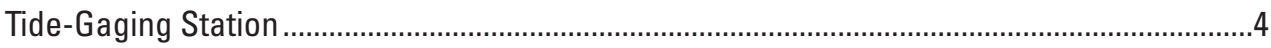

Acoustic Doppler Velocity Meter and Water-Quality Monitor .....................................................

Acoustic Doppler Current Profiler Measurements ..............................................................

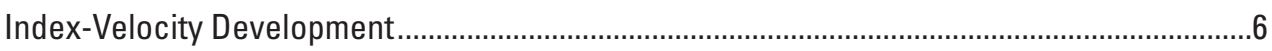

Suspended-Sediment Data ............................................................................................

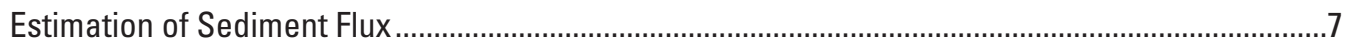

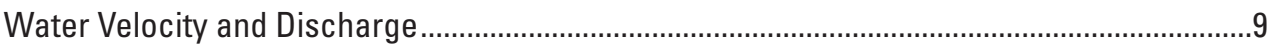

Sediment Concentration and Flux ........................................................................................

Discussion of Sediment Flux to Jamaica Bay: Role of Storms and Other Factors .........................12

Examples of Sediment Flux from a Coastal Storm...............................................................13

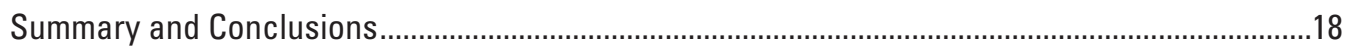

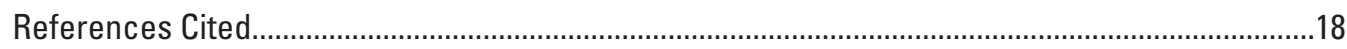

Appendix 1. Data Tables and Statistics for Stage-Area, Index-Velocity, and Turbidity-

Suspended-Sediment-Concentration Ratings for U.S. Geological Survey Tide-Gaging

Station 01311875, Rockaway Inlet at Floyd Bennett Field, New York.

\section{Figures}

1. Map showing part of the northeastern United States, including U.S. Geological Survey tide-gaging stations along the Hudson River and other waterbodies that drain into the Atlantic Ocean, and location of the Jamaica Bay study area.

2. Aerial photograph showing the Jamaica Bay study area, with wetlands (salt marsh) in Jamaica Bay (within the Gateway National Recreation Area), and U.S. Geological Survey tide-gaging station 01311875 near the center of Rockaway Inlet, Jamaica Bay, New York

3. Photograph showing U.S. Geological Survey tide-gaging station 01311875 on bridge protection pier for Marine Parkway-Gil Hodges Memorial Bridge, Rockaway Inlet at Floyd Bennett Field, New York

4. Photographs showing a stainless-steel sliding mount fastened to the inside of a wooden fender structure $A$, deployed, $B$, raised, and $C$, with acoustic Doppler velocity meter and water-quality monitor raised for servicing.

5. Photographs showing a water-quality monitor with antifouling measures: $A$, monitor body with copper tape and brass probe guard and $B$, copper-taped monitor bulkhead, brass turbidity probe, and copper mesh over conductivity/ temperature probe

6. Photographs showing a boat-mounted acoustic Doppler current profiler on $A$, 16-foot aluminum Workskiff with $B$, adjustable aluminum mount 
7. Photograph showing the collection of a fixed-point sample of suspended-sediment concentration by using a Kemmerer sampler adjacent to the turbidity probe at the tide-gaging station.

8. Photographs showing the collection of depth-integrated, equal discharge increment samples of suspended-sediment concentration: $A, \mathrm{D}-96-\mathrm{A} 1$ sampler, and $B$, transferring water from sample bag into polyethylene bottle...

9. Graph showing index-velocity rating, determined by using simple linear regression, based on 58 discharge measurements made during March 2015 in Rockaway Inlet at Jamaica Bay, New York

10. Graph showing validation of the index-velocity rating based on March 2015 measurements (fig. 9) by 43 validation discharge measurements made during 2015-16 in Rockaway Inlet at Jamaica Bay, New York.

11. Graph showing relation between suspended-sediment concentration and turbidity derived from fixed-point data and compared to equal discharge increment data, 2015-16, at Rockaway Inlet at Jamaica Bay, New York.

12. Graph showing suspended-sediment load at Rockaway Inlet at Jamaica Bay, New York, from November 2014 to December 2016

13. Satellite image showing New York metropolitan area and sediment-laden Hudson River discharging to New York Harbor (and New York Bight) after heavy rain associated with Hurricane Irene, August 31, 2011

14. Graphs showing $A$, estuary or ocean water-surface elevation and $B$, turbidity at Rockaway Inlet at Jamaica Bay, New York (U.S. Geological Survey tide-gaging station 01311875) from September 23 to October 11, 2015, during a period of high winds and minor coastal flooding associated with Hurricane Joaquin.

15. Graph showing suspended-sediment load at Rockaway Inlet at Jamaica Bay, New York (U.S. Geological Survey tide-gaging station 01311875), from September 23 to October 11, 2015, spanning the period October 1-2, when Hurricane Joaquin passed off the eastern U.S. seaboard

16. Graph showing $A$, tidal elevation and $B$, turbidity at Rockaway Inlet at Jamaica Bay, New York (U.S. Geological Survey tide-gaging station 01311875), during 0 ctober 1-2, 2015, while Hurricane Joaquin passed off the eastern U.S. seaboard

\section{Tables}

1. Dates and tidal notes for fixed-point sampling of suspended-sediment concentration, in Rockaway Inlet at Jamaica Bay, New York

2. Dates and tidal notes for equal discharge increment (EDI) sampling of suspended-sediment concentration, in Rockaway Inlet at Jamaica Bay, New York

3. Acoustic Doppler current profiler discharge measurement dates, numbers, and remarks, in Rockaway Inlet at Jamaica Bay, New York. 


\section{Conversion Factors}

U.S. customary units to International System of Units

\begin{tabular}{lll}
\hline \multicolumn{1}{c}{ Multiply } & By & \multicolumn{1}{c}{ To obtain } \\
\hline inch (in.) & 2.54 & centimeter $(\mathrm{cm})$ \\
inch (in.) & 25,400 & micrometer $(\mu \mathrm{m})$ \\
foot (ft) & 0.3048 & meter $(\mathrm{m})$ \\
mile (mi) & 1.609 & kilometer $(\mathrm{km})$ \\
square mile $\left(\mathrm{mi}^{2}\right)$ & 2.590 & square kilometer $\left(\mathrm{km}^{2}\right)$ \\
cubic foot per second $\left(\mathrm{ft}^{3} / \mathrm{s}\right)$ & 0.02832 & cubic meter per second $\left(\mathrm{m}^{3} / \mathrm{s}\right)$ \\
pound per second $(\mathrm{lb} / \mathrm{s})$ & 0.4536 & kilogram per second $(\mathrm{kg} / \mathrm{s})$ \\
mile per hour $(\mathrm{mi} / \mathrm{hr})$ & 1.609 & kilometer per hour $(\mathrm{km} / \mathrm{hr})$ \\
\hline
\end{tabular}

\section{Datum}

Vertical coordinate information is referenced to the National Geodetic Vertical Datum 1929 (NGVD 29).

Horizontal coordinate information is referenced to the North American Datum of 1927 (NAD 27), the North American Datum of 1983 (NAD 83), or the World Geodetic System of 1984 (WGS 84).

Elevation, as used in this report, refers to distance above the vertical datum.

\section{Supplemental Information}

Concentrations of chemical constituents in water are given in milligrams per liter ( $\mathrm{mg} / \mathrm{L})$.

Turbidity is given as formazin nephelometric units (FNU).

\section{Abbreviations}

$\begin{array}{ll}\text { ADCP } & \text { acoustic Doppler current profiler } \\ \text { ADVM } & \text { acoustic Doppler velocity meter } \\ \text { EDI } & \text { equal discharge increment } \\ \text { NYCDEP } & \text { New York City Department of Environmental Protection } \\ \text { NYSDEC } & \text { New York State Department of Environmental Conservation } \\ \text { SSC } & \text { suspended-sediment concentration } \\ \text { USGS } & \text { U.S. Geological Survey }\end{array}$





\title{
Estimating Sediment Flux to Jamaica Bay, New York
}

\author{
By Richard A. Cartwright and Amy E. Simonson
}

\section{Abstract}

Tidal wetland loss in Jamaica Bay, New York, is well documented. Maintaining wetlands is important from an environmental and ecological perspective and because wetlands buffer coastal communities from storm damage. An estimate of suspended-sediment flux through Rockaway Inlet is needed to improve understanding of sediment dynamics in Jamaica Bay and could be used in salt marsh restoration efforts. To estimate sediment flux, an index-velocity station and turbidity sensor were installed and operated in Rockaway Inlet near the mouth of Jamaica Bay from November 2014 to December 2016 and point and cross-sectional suspended-sediment samples were collected and analyzed. Index-velocity data coupled with cross-sectional acoustic Doppler current profiler measurements were used to develop an index-velocity rating. A simple linear regression rating with a strong coefficient of determination $\left(\mathrm{R}^{2}\right.$ of 0.981$)$ was developed. Discharge was computed from the stage-area and index-velocity relations, and a lowpass Godin filter was used to remove the tidal aliasing. A second simple linear regression $\left(\mathrm{R}^{2}\right.$ of 0.75$)$ between fixed-point suspended-sediment concentration (SSC) samples and turbidity allowed for the calculation of SSC through Rockaway Inlet, and then sediment flux was found by multiplying SSC and discharge for continuous (6-minute) data. Turbidity values were low in the near-ocean conditions at Rockaway Inlet, with daily means ranging from 0.6 to 8.2 formazin nephelometric units during the period of November 2014 through December 2016. During this time, computed daily mean suspendedsediment concentrations ranged from 3 to 13 milligrams per liter. High sediment loads generally occurred during incoming tides, during both storm and nonstorm conditions, suggesting a net inward sediment flux into Jamaica Bay. The fate of sediment after it enters Jamaica Bay was not investigated. Trends in sediment flux during major storms could not be evaluated because no major storms occurred during this investigation.

\section{Introduction}

Tidal wetlands provide many environmental and ecological benefits, such as acting to buffer coastal communities from storm damage. However, wetland loss along the Atlantic coast of the United States is well documented (Dahl and Stedman, 2013). Similar wetland loss is also reported for Jamaica Bay (Hartig and others, 2002), one of the largest tidal wetland ecosystems in New York State (fig. 1). In 2001, mapping analysis by the New York State Department of Environmental Conservation (NYSDEC) showed that between 1924 and 1999, half of the bay's vegetated marsh islands disappeared and that the rate of loss was increasing. Assuming that rate of loss continues baywide into the future, it was calculated that the marsh islands would completely vanish by 2024 (NYSDEC, 2001).

Recent salt marsh restoration efforts in Jamaica Bay by the New York City Department of Environmental Protection (NYCDEP), along with many other government agencies such as the NYSDEC, the U.S. Army Corps of Engineers, the National Park Service, the New York City Department of Parks and Recreation, and the Port Authority of New York and New Jersey, are part of an ongoing restoration and ecological improvement plan for Jamaica Bay, as outlined in the Jamaica Bay Watershed Protection Plan (NYCDEP, 2007). The health and sustainability of these restored and existing tidal salt marshes is driven by many dynamic processes, of which sediment supply "may be the most critical" (Hartig and others, 2002, p. 87). Therefore, understanding sediment-flux dynamics within the wetland is a crucial part of restoration and stability.

The U.S. Geological Survey (USGS) Woods Hole Coastal and Marine Science Center was awarded U.S. Department of the Interior Hurricane Sandy supplemental funding (project GS2-2D) to assess the estuarine and adjacent wetland responses of three Atlantic lagoonal estuaries to major storm events such as Hurricane Sandy, one of which is Jamaica Bay. This assessment includes the measuring and comparing of net sediment fluxes to the wetland complex and estuary with modeled sediment fluxes. The assessment also includes the testing of high-resolution models of hydrodynamics and sediment transport in vegetated salt marshes to evaluate depositional patterns as well as vulnerability of salt marsh shorelines to wave attack.

To provide data for the above-mentioned model design and calibration, a tide-gaging station, at which an index-velocity meter and a continuous turbidity monitor were installed, was operated in Rockaway Inlet (USGS tide-gaging station 01311875; fig. 2) during a 2-year period from November 2014 to December 2016. Data at the station were correlated with cross-channel acoustic Doppler current profiler (ADCP) measurements for velocity and suspended-sediment concentration (SSC) samples for turbidity. SSC samples were collected by using two methods: depth-integrated equal discharge increment (EDI) sampling across Rockaway Inlet, and fixed-point SSC samples at the monitoring location. 


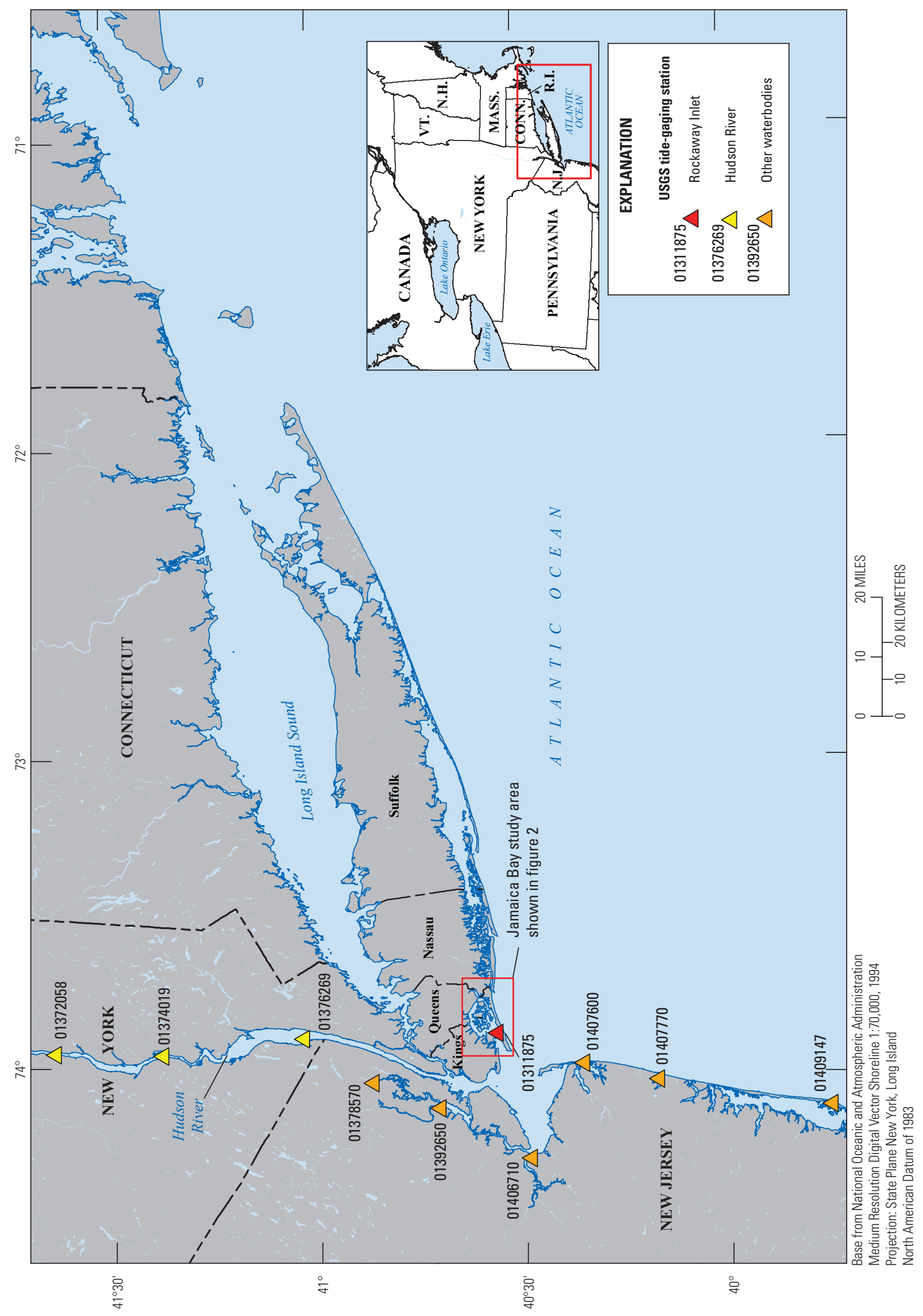

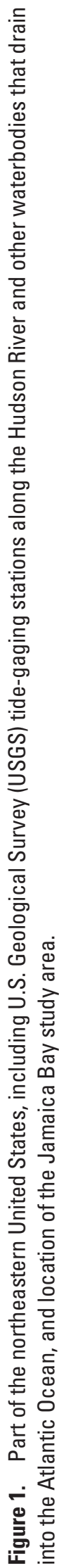




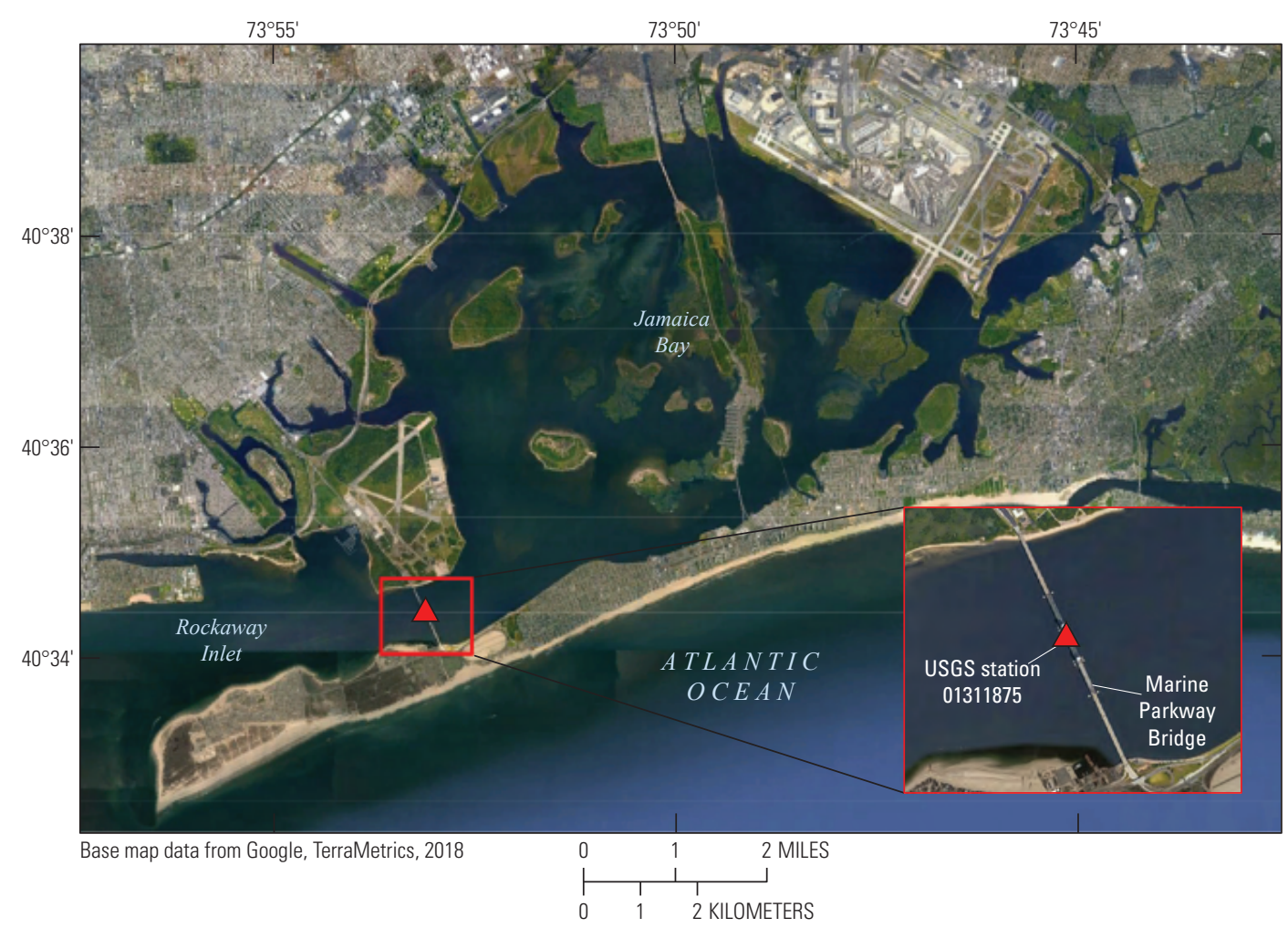

Figure 2. The Jamaica Bay study area, with wetlands (salt marsh) in Jamaica Bay (within the Gateway National Recreation Area), and U.S. Geological Survey (USGS) tide-gaging station 01311875 near the center of Rockaway Inlet, Jamaica Bay, New York.

\section{Purpose and Scope}

The purpose of this report is to document and describe the methodologies used to design, install and operate a sediment-flux monitoring system for estimating sediment flux to Jamaica Bay, New York, and to analyze how the resulting estimates may correlate with storms and other factors.

\section{Jamaica Bay Study Area}

Jamaica Bay comprises about 31 square miles in southern parts of Kings, Queens, and western Nassau Counties, N.Y. (figs. 1 and 2). It is one of the largest tidal wetland ecosystems in New York State and is a component of the National Park Service's Gateway National Recreation Area. The bay is a diverse ecological resource that supports multiple habitats, including open water, salt marshes, grasslands, coastal woodlands, maritime shrublands, and brackish and freshwater wetlands. These habitats support 91 fish species, 325 bird species, and many reptile, amphibian, and small mammal species (NYCDEP, 2007).

During the last 150 years, wetlands have been removed as a result of extensive filling operations; shorelines have been hardened and bulk-headed; deep channels and borrow areas have been dredged, altering bottom contours and affecting natural flows; and natural tributaries have essentially disappeared, leaving behind deposits of silts and particulates from urban runoff. These activities have synergistically affected historical flow and sediment deposition and removal patterns in the bay, damaged natural habitat, affected water quality, and changed the once rich ecosystem (NYCDEP, 2007).

\section{Methods of Data Collection and Analysis}

To quantify net sediment flux to Jamaica Bay though Rockaway Inlet, a continuous monitoring system, composed of the following three permanently mounted components, was employed: (1) a tide-gaging station, (2) an acoustic Doppler velocity meter (ADVM), and (3) a water-quality monitor. Components 1 and 2 make up the index-velocity station. The index-velocity method is a way to compute continuous records of discharge (Levesque and Oberg, 2012), especially in a tidally affected environment (Ruhl and Simpson, 2005). Discharge is computed as the product of cross-sectional area and mean velocity. The cross-sectional area is based on a water elevation (or stage) versus area relation that is determined from a detailed channel survey. The mean cross-sectional 
velocity is computed from discharge measurements made with an ADCP (Mueller and Wagner, 2009) and is related to the index velocity recorded by the station's ADVM. All continuous time-series data are recorded at 6-minute intervals, stored onsite, and then transmitted to USGS offices by satellite and telephone telemetry. The continuous data are correlated with cross-sectional ADCP data and SSC data to estimate sediment flux.

\section{Tide-Gaging Station}

The tide-gaging station was designed and installed on a bridge protection pier near the middle of Rockaway Inlet on the Marine Parkway-Gil Hodges Memorial Bridge in 2002. The station was equipped with a Sutron Accubar Constant Flow Bubble Gauge connected to a Sutron 9210 data-collection platform mounted several feet above the 100-year coastal-flood elevation inside a reinforced shelter (fig. 3). A 2-inch-diameter, brass standpipe extending into the water column protects the pressurized orifice line from damage and minimizes biofouling.

\section{Acoustic Doppler Velocity Meter and Water- Quality Monitor}

In November 2014, a 500-kilohertz side-looker ADVM (Sontek SL500) and a water-quality monitor (YSI 6600 multiparameter monitor) were installed adjacent to the orifice line standpipe for the tide-gaging station. A stainless-steel mount with sliding assembly was custom-designed and fabricated so that the ADVM and water-quality equipment could be raised and lowered for routine maintenance, cleaning, and calibration (fig. 4). Considerations for site selection, installation procedures, and data processing follow guidelines outlined in Levesque and Oberg (2012). The monitor provides continuous water temperature, specific conductance (used to compute salinity) and turbidity data from near midwater depth. To minimize biofouling, the monitor body and probes are enclosed in either brass or copper (fig. 5). A sponge wiper maintains a clean optical surface on the turbidity probe. A manually operated come-along winch is used to raise the sliding mount assembly for monitor servicing. Servicing and maintenance procedures include the calculation of fouling and drift corrections and follow USGS standard procedures for continuous monitors (Wagner and others, 2006). Routine visits and maintenance are scheduled for 4-week intervals in the summer, 6-week intervals in the spring and fall, and 8-week intervals during the winter. From November 2014 through December 2016, daily mean turbidity values ranged from 0.6 to 8.2 formazin nephelometric units (FNU).

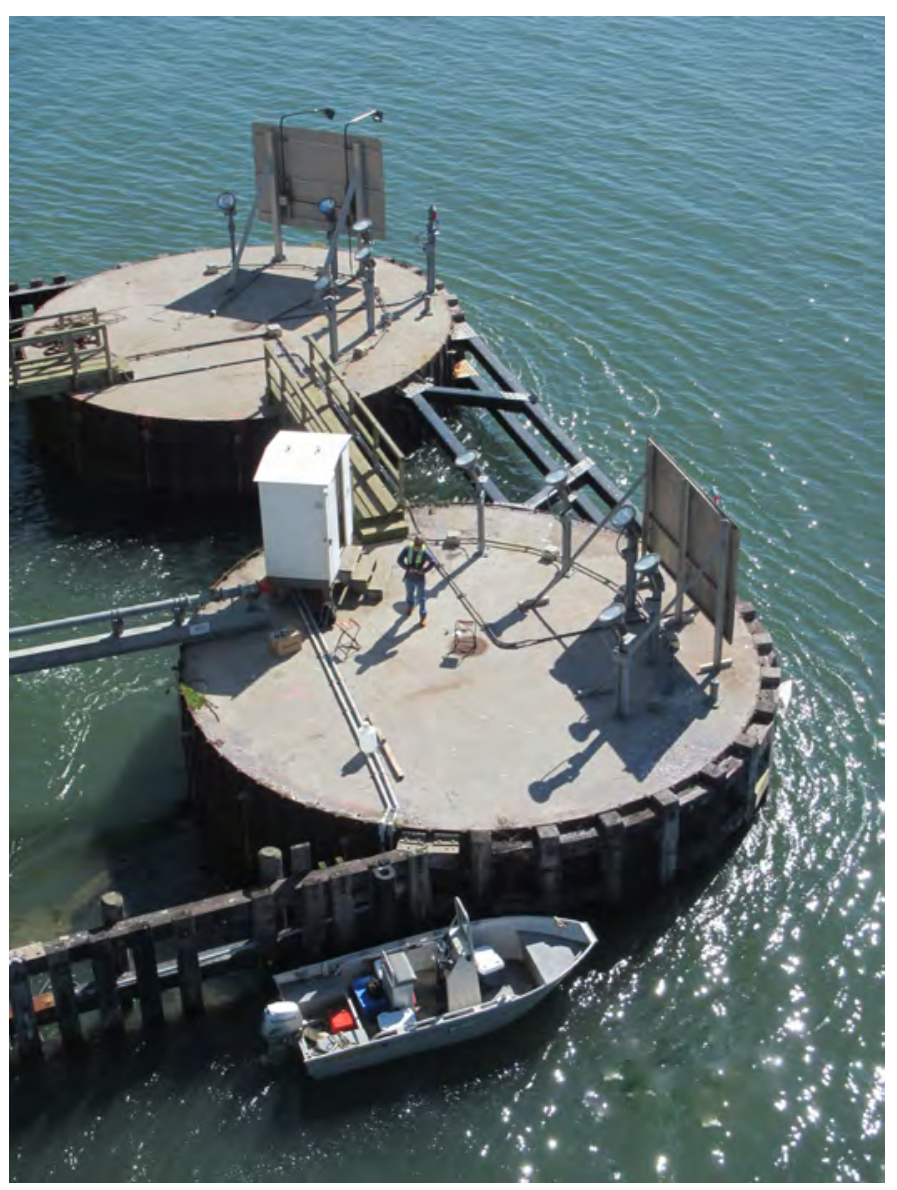

Figure 3. U.S. Geological Survey tide-gaging station 01311875 on bridge protection pier for Marine Parkway-Gil Hodges Memorial Bridge, Rockaway Inlet at Floyd Bennett Field, New York. Photograph by R. Cartwright, U.S. Geological Survey.

\section{Acoustic Doppler Current Profiler Measurements}

Prior to installation of the ADVM, 14 reconnaissance discharge measurements were made in April and May 2014 by using a boat-mounted ADCP on a 16-foot aluminum Workskiff (fig. 6) to determine the flow distributions and bathymetry at various locations in Rockaway Inlet. Maximum outgoing (towards ocean) flow when measurements were made was $+195,000$ cubic feet per second, and maximum incoming (towards bay) flow was $-249,000$ cubic feet per second. To develop the relation between the index velocity (as measured by the ADVM) and the mean cross-sectional velocity, an additional 58 ADCP measurements were made. All discharge measurements were made following standard qualityassurance protocols outlined in Mueller and Wagner (2009), including water temperature comparison, salinity measurement with a refractometer, moving bed tests, and compass calibration. Discharge measurements were 12 minutes in duration because this timing allowed for slow, steady channel transects 
$\boldsymbol{A}$

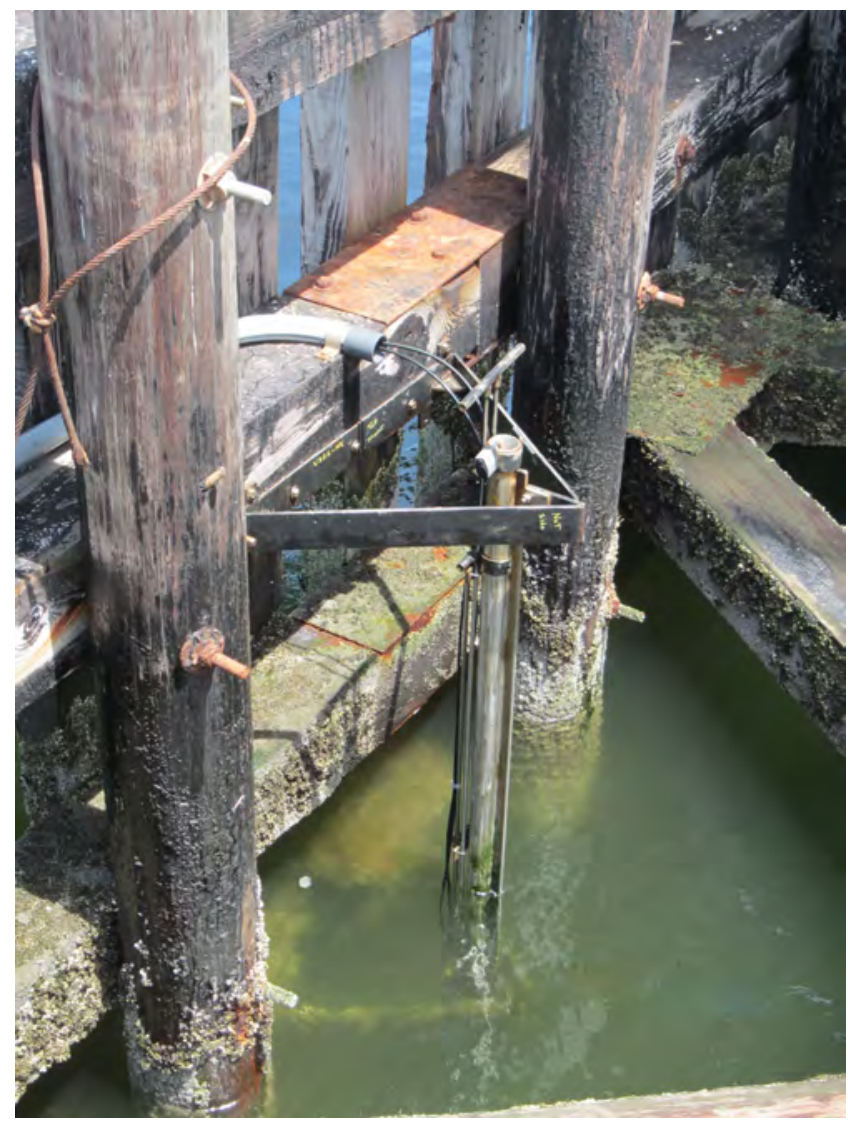

C

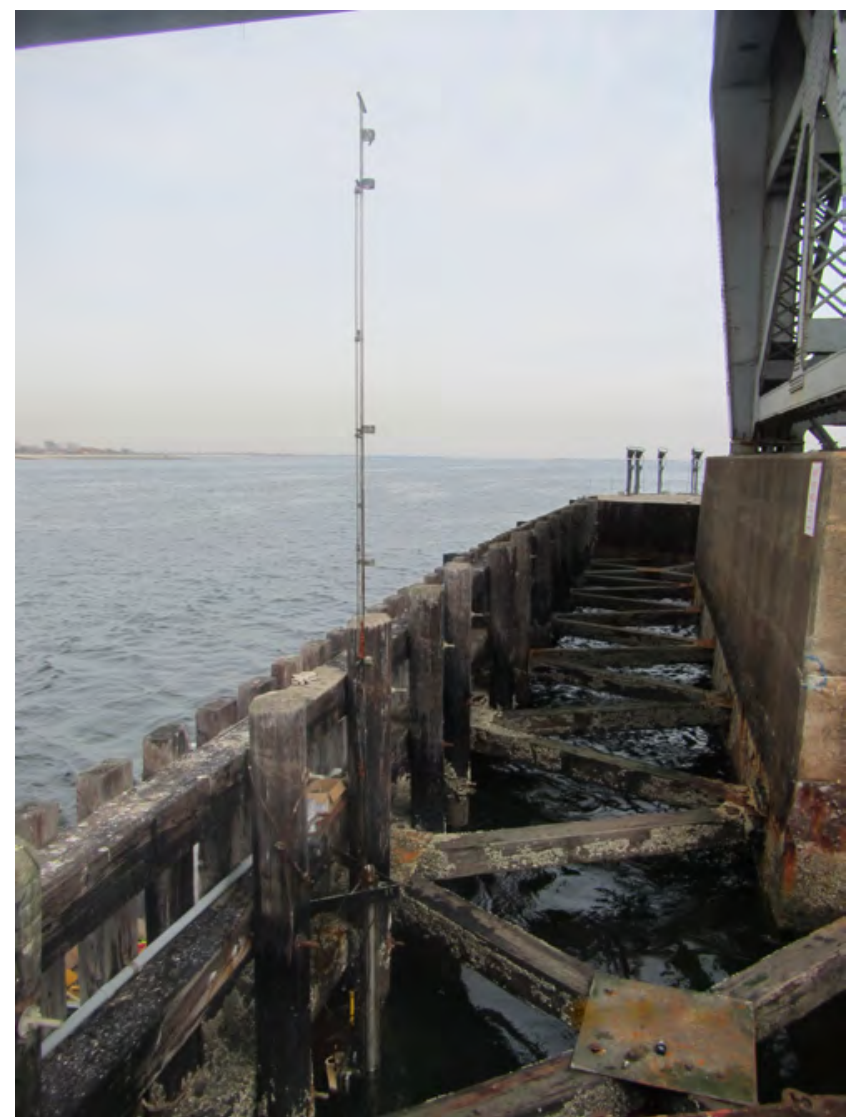

B

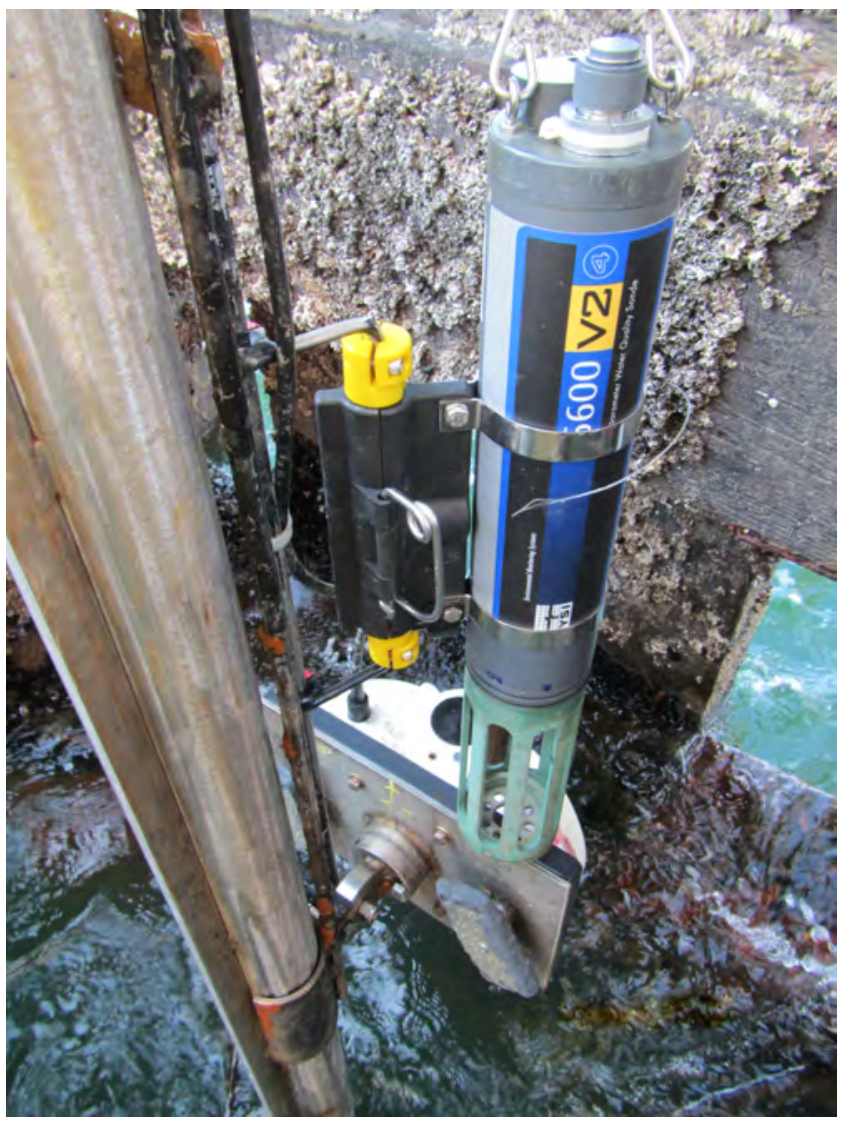

Figure 4. A stainless-steel sliding mount fastened to the inside of a wooden fender structure $A$, deployed, $B$, raised, and $C$, with acoustic Doppler velocity meter and water-quality monitor raised for servicing. Photographs by $\mathrm{R}$. Cartwright, U.S. Geological Survey. 
$\boldsymbol{A}$

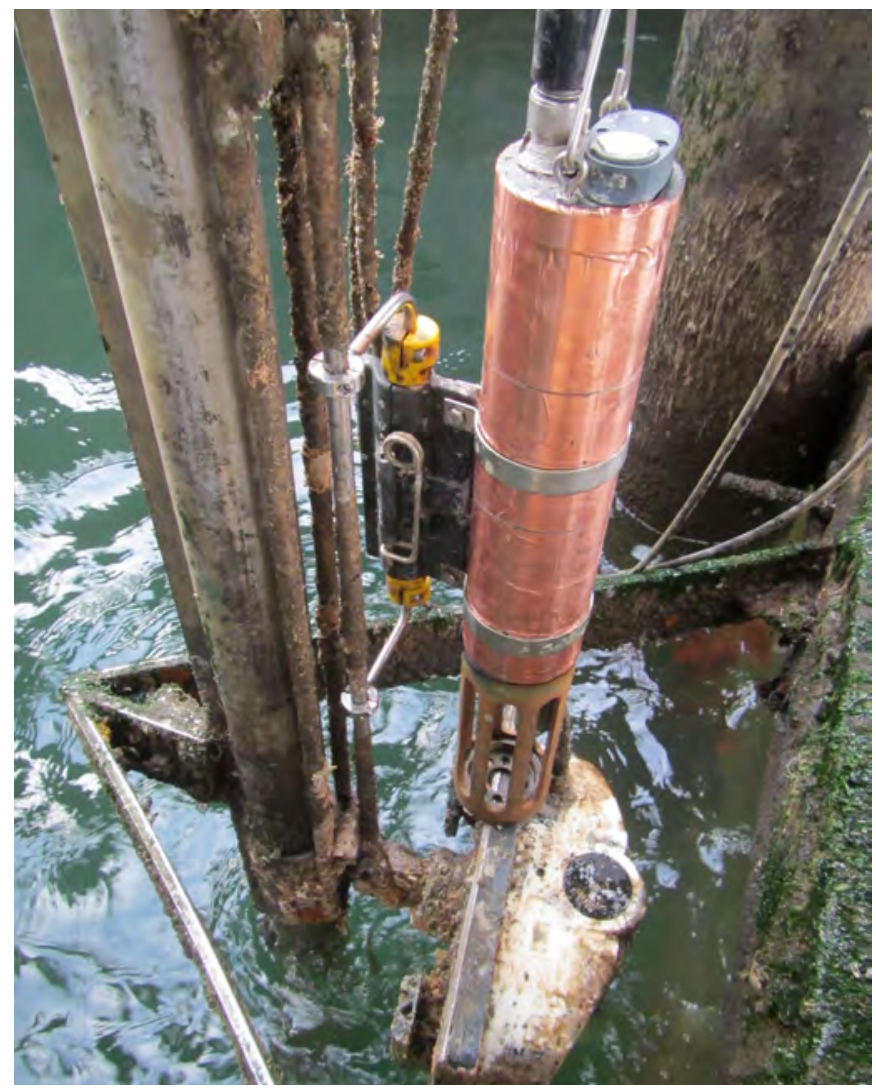

$B$

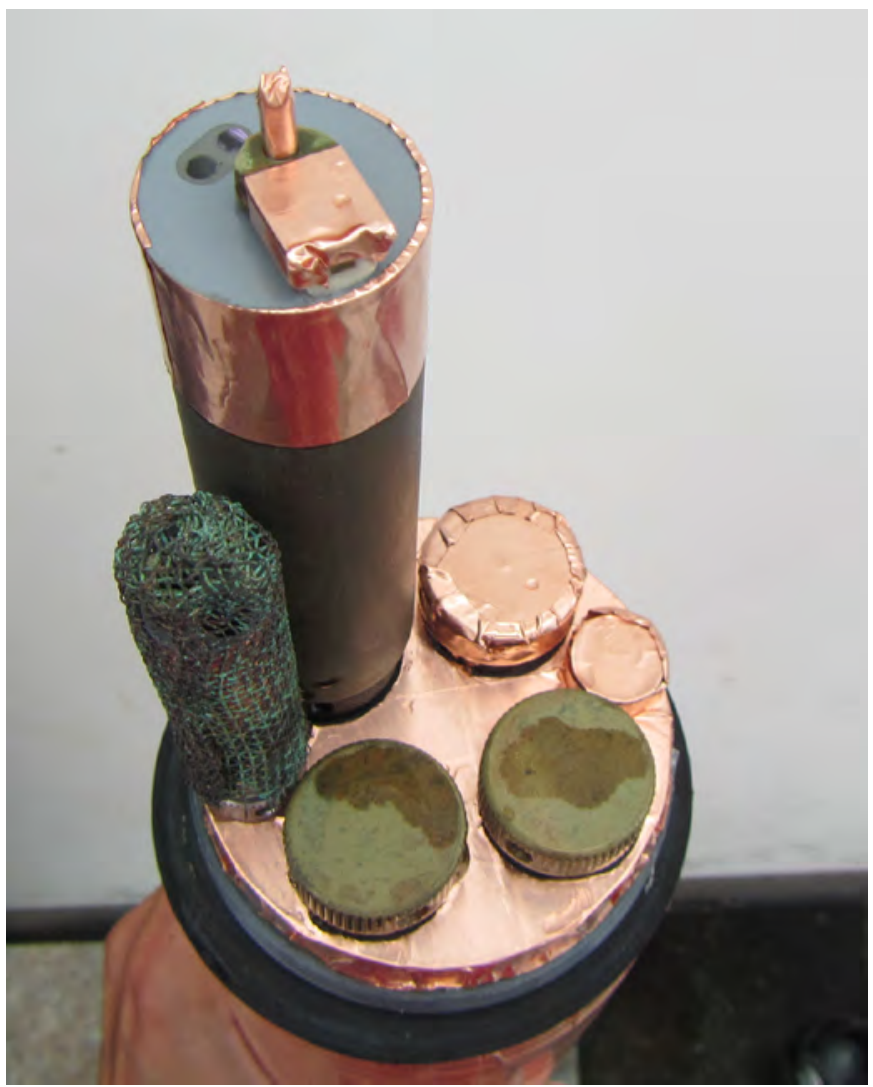

Figure 5. A water-quality monitor with antifouling measures: $A$, monitor body with copper tape and brass probe guard and $B$, coppertaped monitor bulkhead, brass turbidity probe, and copper mesh over conductivity/temperature probe. Photographs by R. Cartwright, U.S. Geological Survey.

while maintaining a multiple of the 6-minute elevation and velocity data measured at the tide-gaging station. Instead of using the standard protocol of a 1-minute velocity recording interval (Levesque and Oberg, 2012), the 6-minute collection interval was used so that data would remain available online to cooperators and flood forecasters during the 6- to 8-hour-long measurement campaigns.

\section{Index-Velocity Development}

The index-velocity method described by Ruhl and Simpson (2005) for computing discharge in tidally influenced environments was used in this study. Discharge was computed as a three-step process: (1) calculating the cross-sectional area based on a stage time-series and bank elevations, (2) calculating the mean cross-sectional velocity based on a measured index-velocity time series, and (3) calculating discharge as the product of the mean velocity and area.

A stage-area rating was developed to relate elevation (stage) and cross-sectional area, using the USGS program AreaComp2 (Levesque and Oberg, 2012; USGS, 2015). A standard cross section was established by surveying the banks with a global navigation satellite system and choosing a representative ADCP measurement for channel bathymetry (appendix 1, table 1.1). The standard cross section runs parallel to and is about 200 feet east of the bridge, and the cross section extends north and south (landward) above the period-of-record maximum elevation from Hurricane Sandy (Schubert and others, 2015).

Initial ADCP measurements were collected in April and May 2014 to help determine ADVM placement and design. By following methods from Levesque and Oberg (2012), the ADVM was programmed to collect multicell data in 10-meter increments from 10 to 110 meters and, to avoid measuring areas of flow disturbance from the bridge protection piers, the ADVM range-averaged the data from 20 to 50 meters. The ADVM was programmed such that cells $2-5$ of the multicell data measured the same area as the range-averaged data. These range-averaged data were the index velocities on which the index-to-mean velocity relation was based. The ADVM was programmed with an averaging interval of 180 seconds and a measurement interval of 360 seconds, to match 6-minute data collection at the tide-gaging station, which is centered on the top of the hour and measured every 6 minutes thereafter. 
$\boldsymbol{A}$

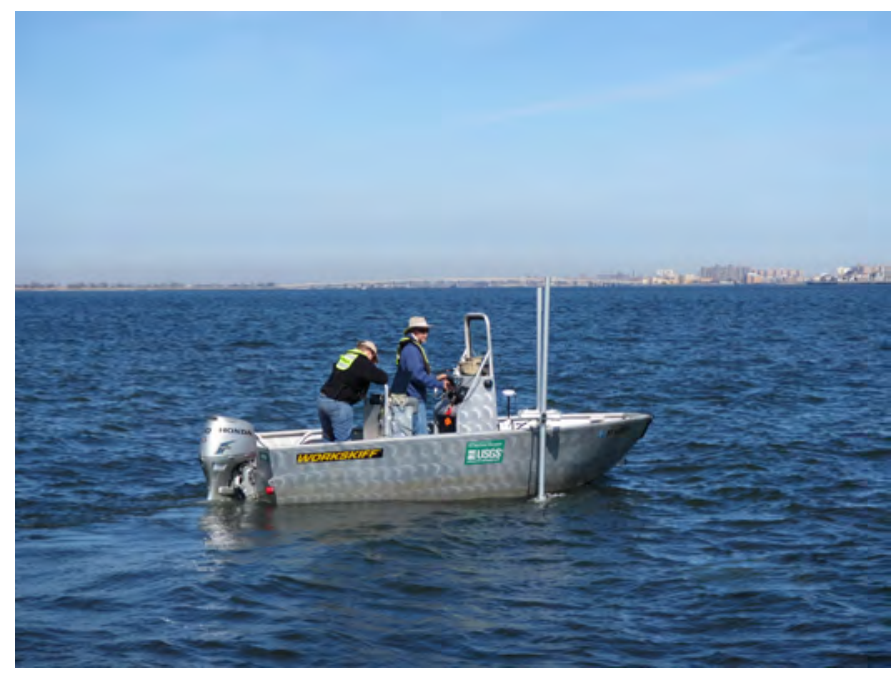

B

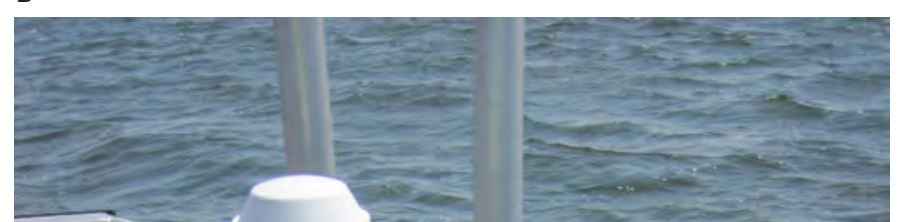

\section{Suspended-Sediment Data}

Two different sets of SSC data were collected and analyzed: (1) fixed-point samples were collected adjacent to the turbidity probe to develop a relation between turbidity and SSC at the tide-gaging station, and (2) depth-integrated samples were collected at equal discharge increments (EDIs) across Rockaway Inlet and analyzed individually to define cross-sectional variability.

Fixed-point samples were collected concurrently with 6-minute turbidity readings using a Kemmerer sampler (fig. 7) lowered to near midwater depth adjacent to the turbidity probe. A total of 51 fixed-point samples were collected for SSC between 2015 and 2016 (table 1; also in appendix 1, table 1.3). On September 28 and October 6, 2015, 27 fixedpoint samples were collected throughout incoming tidal cycles for spring-tide conditions. On May 26, 2016, an additional 24 fixed-point samples were collected throughout a semidiurnal tidal cycle during neap-tide conditions. The October fixedpoint samples were collected when storm-related high-turbidity values were being recorded, with the intent of collecting water samples with high SSC values.

Depth-integrated EDI samples were collected across Rockaway Inlet from a boat with a D-96-A1 collapsible-bag sampler for suspended sediment and water quality (USGS, variously dated; fig. 8) to determine the cross-sectional variability of SSC. A discrete sample was collected and analyzed at each of the five EDI sampling locations, from which a mean SSC value was calculated by averaging the concentrations of the individual samples. A total of 43 EDI samples-including 5 at 8 cross sections and several replicate samples-were collected for SSC analysis between 2015 and 2016 (table 2; also in appendix 1, table 1.3). Of these 43 EDI samples, 11 are sequential replicate samples because they were collected at the same location over a short time (USGS, 2004). Twenty EDI samples were collected for SSC analysis in April 2015 during peak ebb and flood conditions of spring tide, when water velocity and turbidity values are typically high. Twenty-three EDI samples were collected for SSC analysis in April 2016 during ebb and flood conditions of neap tide, when maximum water velocity and turbidity values are typically low.

For both collection methods, water samples were transferred from the sampler to pretared, 3-liter polyethylene sample bottles and stored in a refrigerator prior to shipment for laboratory analysis. Samples were analyzed by the USGS Kentucky Water Science Center Sediment Laboratory for SSC and the mass percentage of the sediment less than sand size (62.5 micrometers) (Shreve and Downs, 2005).
Figure 6. A boat-mounted acoustic Doppler current profiler on $A, 16$-foot aluminum Workskiff with $B$, adjustable aluminum mount. Photographs by U.S. Geological Survey.

\section{Estimation of Sediment Flux}

Discharge and SSC were determined by correlating discrete measurements with continuous data, then the sediment flux was calculated by multiplying the two parameters (Rasmussen and others, 2009, p. 22). 


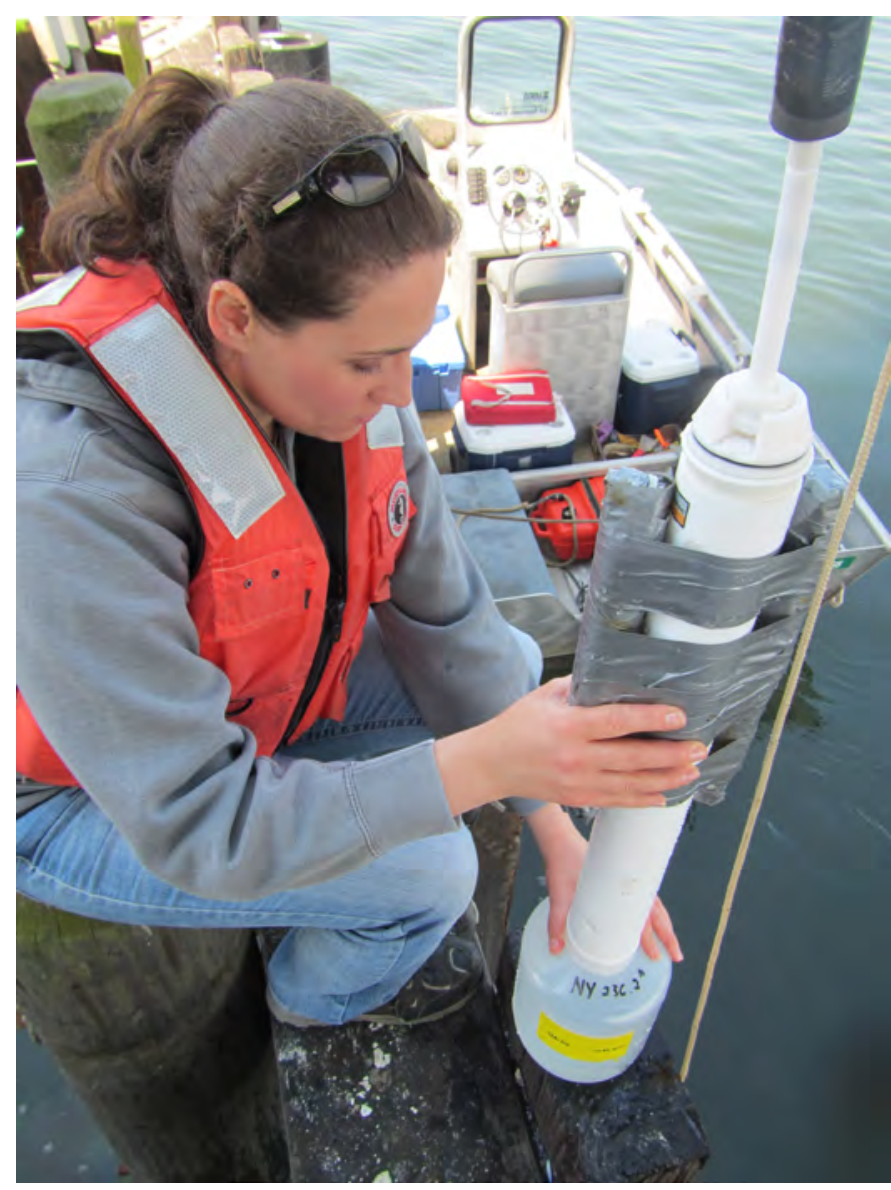

Figure 7. The collection of a fixed-point sample of suspendedsediment concentration by using a Kemmerer sampler adjacent to the turbidity probe at the tide-gaging station. Weights taped to the sampler keep it from swinging in tidal currents. Photograph by R. Cartwright, U.S. Geological Survey.

Table 1. Dates and tidal notes for fixed-point sampling of suspended-sediment concentration, in Rockaway Inlet at Jamaica Bay, New York. Fixed-point samples were collected adjacent to the turbidity probe at the tide-gaging station.

\begin{tabular}{lcl}
\hline \multicolumn{1}{c}{ Date } & $\begin{array}{c}\text { Number of } \\
\text { samples }\end{array}$ & \multicolumn{1}{c}{ Tidal conditions } \\
\hline Sept. 28, 2015 & 12 & Spring tide, incoming \\
Oct. 6, 2015 & 15 & Spring tide, incoming \\
May 26, 2016 & 24 & Neap tide, incoming and outgoing \\
Total & $\mathbf{5 1}$ & \\
\hline
\end{tabular}

Table 2. Dates and tidal notes for equal discharge increment (EDI) sampling of suspended-sediment concentration, in Rockaway Inlet at Jamaica Bay, New York. EDI samples were collected approximately 200 feet east of tide-gaging station.

\begin{tabular}{lcl}
\hline \multicolumn{1}{c}{ Date } & $\begin{array}{c}\text { Number of } \\
\text { samples }\end{array}$ & \multicolumn{1}{c}{ Tidal conditions } \\
\hline Apr. 18, 2015 & 20 & Spring tide, outgoing and incoming \\
Apr. 13, 2016 & 10 & Neap tide, outgoing \\
Apr. 14, 2016 & 13 & Neap tide, incoming \\
Total & $\mathbf{4 3}$ & \\
\hline
\end{tabular}

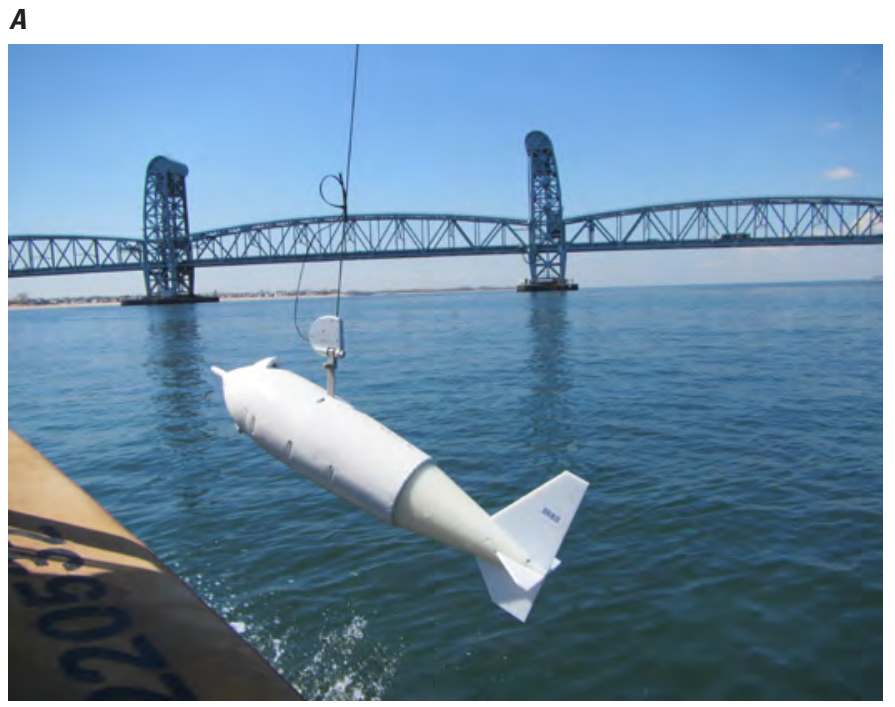

$B$

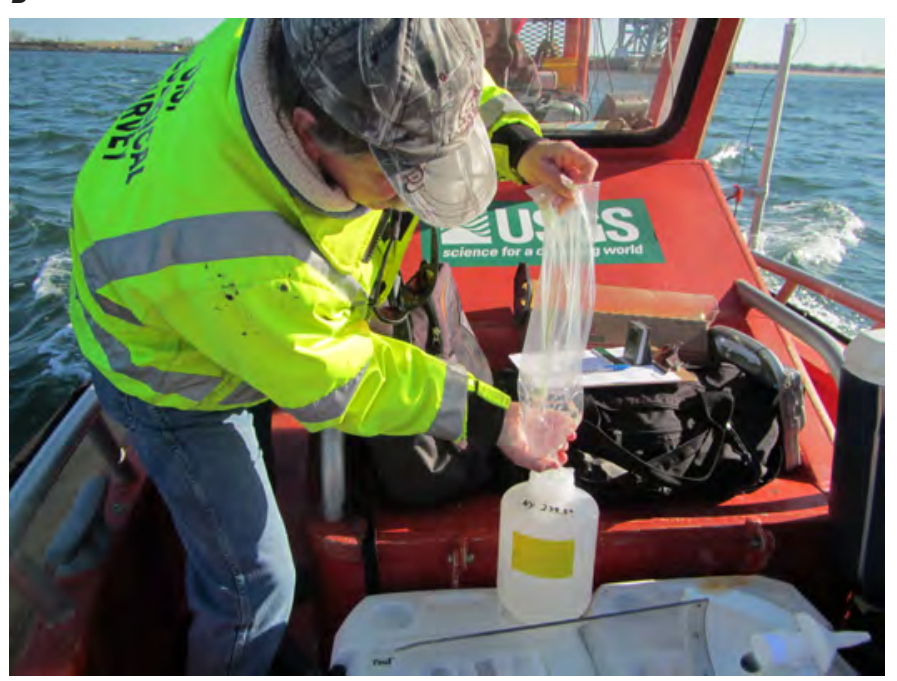

Figure 8. The collection of depth-integrated, equal discharge increment samples of suspended-sediment concentration: $A$, D-96-A1 sampler, and $B$, transferring water from sample bag into polyethylene bottle. Photographs by U.S. Geological Survey. 


\section{Water Velocity and Discharge}

In March 2015, 58 ADCP measurements were made during spring tides with the intent of measuring the full range of water velocity (table 3 ). These measurements (numbers 15-72; USGS, 2017b) were correlated with ADVM-observed data to develop an index-velocity rating (fig. 9) by using methods described in Levesque and Oberg (2012) and the Surrogate Analysis and Index Developer (SAID) tool (Domanski and others, 2015). A simple linear regression was developed by correlating mean channel velocity for measurements made on March 21 and 23, 2015, with the range-averaged measured velocity at the ADVM (fig. 9; appendix 1, table 1.2):

$$
\text { Vmean }=0.923 \times V i+0.024,
$$

where

Vmean is the mean cross-sectional velocity, in feet per second, and

$\mathrm{Vi}$ is the average index velocity measured by the ADVM, in feet per second.

This regression produced a strong coefficient of determination ( $\mathrm{R}^{2}$ of 0.981$)$, and the residual plots were normally distributed and of equal variance (Riggs, 1968, p. 7). An additional 43 ADCP measurements were made from 2015 to 2016 and plot well within the 95-percent prediction interval (USGS, 2017a) of the initial March 2015 measurements (fig. 10).

Therefore, a more complex index-velocity relation-such as a quadratic, loop, or bimodal rating - that is more commonly used for a tidal environment (Ruhl and Simpson, 2005) was not necessary to compute discharge.

Discharge was computed by multiplying the output from the stage-area and index-velocity relations. Because this gaging station is in a tidal environment, and because of the difference between the solar period ( 24 hours) and the lunar period (24 hours and 50 minutes), an unbiased daily discharge cannot be determined by averaging all values collected in a 24-hour period. To account for this difference in solar and lunar periodicity, a low-pass Godin filter (Godin, 1972; Ruhl and Simpson, 2005), which removes frequencies that have periods less than 30 hours and effectively removes variations due to astronomical tides, was used. Without a filter, there would be an apparent oscillation, or tidal aliasing, within the computed daily value time series that would be unrelated to physical conditions (USGS, 2011). The daily mean discharge was computed as the daily average of the low-pass-filtered discharge.

\section{Sediment Concentration and Flux}

As previously described in the section "SuspendedSediment Data," results from analyses of suspended-sediment concentration were used for two purposes: (1) fixed-point samples collected near the turbidity probe were used to develop a relation between turbidity and SSC at the tide-gaging station;
Table 3. Acoustic Doppler current profiler discharge measurement dates, numbers, and remarks, in Rockaway Inlet at Jamaica Bay, New York.

\begin{tabular}{lrl}
\hline Date & $\begin{array}{c}\text { Measurement } \\
\text { number }\end{array}$ & \multicolumn{1}{c}{ Remark } \\
\hline Apr. 25, 2014 & $1-8$ & Reconnaissance \\
May 13, 2014 & $9-14$ & Reconnaissance \\
Mar. 21, 2015 & $15-46$ & Index-velocity rating \\
Mar. 23, 2015 & $47-72$ & Index-velocity rating \\
May 7, 2015 & $73-78$ & Rating validation \\
Oct. 27, 2015 & $79-103$ & Rating validation \\
Apr. 14, 2016 & $104-109$ & Rating validation \\
Dec. 14, 2016 & $110-115$ & Rating validation \\
\hline
\end{tabular}

and (2) cross-sectional, depth-integrated samples were used to define cross-sectional variability of SSC.

Forty-three cross-sectional, depth-integrated EDI samples were collected in April 2015 and April 2016 during peak flood and ebb tides. Overall, SSCs ranged from 2 to 8 milligrams per liter $(\mathrm{mg} / \mathrm{L})$ (1.2 to 1.6 formazin nephelometric units [FNU]) during ebb tide and from 4 to $11 \mathrm{mg} / \mathrm{L}$ (2.0 to 2.7 FNU) during flood tide. Physical limitations of sample collection prevented sampling across the channel during high-turbidity events (usually storms). To supplement these data, an additional 51 fixed-point samples were collected in September and October 2015 and May 2016, with SSC values ranging from 3 to $20 \mathrm{mg} / \mathrm{L}$ and corresponding turbidity values ranging from 1.7 to 12 FNU. Figure 11 shows the simple linear regression $\left(\mathrm{R}^{2}\right.$ of 0.75 ; appendix 1 , table 1.3$)$ between fixed-point SSC and turbidity and the 90-percent prediction interval (Rasmussen and others, 2009), plotted with the mean EDI SSC data:

$$
S S C=1.29 \times \operatorname{Turb}+2.52,
$$

where

$$
\begin{aligned}
& \text { SSC is suspended-sediment concentration, in } \\
& \mathrm{mg} / \mathrm{L} \text {; and }
\end{aligned}
$$

Turb is turbidity, in FNU.

The mean EDI SSCs plot within the prediction interval of the SSCs determined by the fixed-point-SSC to turbidity regression relation (although they are clustered around the lower end because of practicality of sampling during storms), which supports the assumption that the fixed-point SSCs are representative of the mean SSC across the entire cross section and thereby validates the fixed-point-SSC to turbidity relation as a means to estimate sediment loads in this reach, particularly at lower turbidities and SSCs. During the November 2014 to December 2016 study period, daily mean suspendedsediment concentrations ranged from 3 to $13 \mathrm{mg} / \mathrm{L}$. 


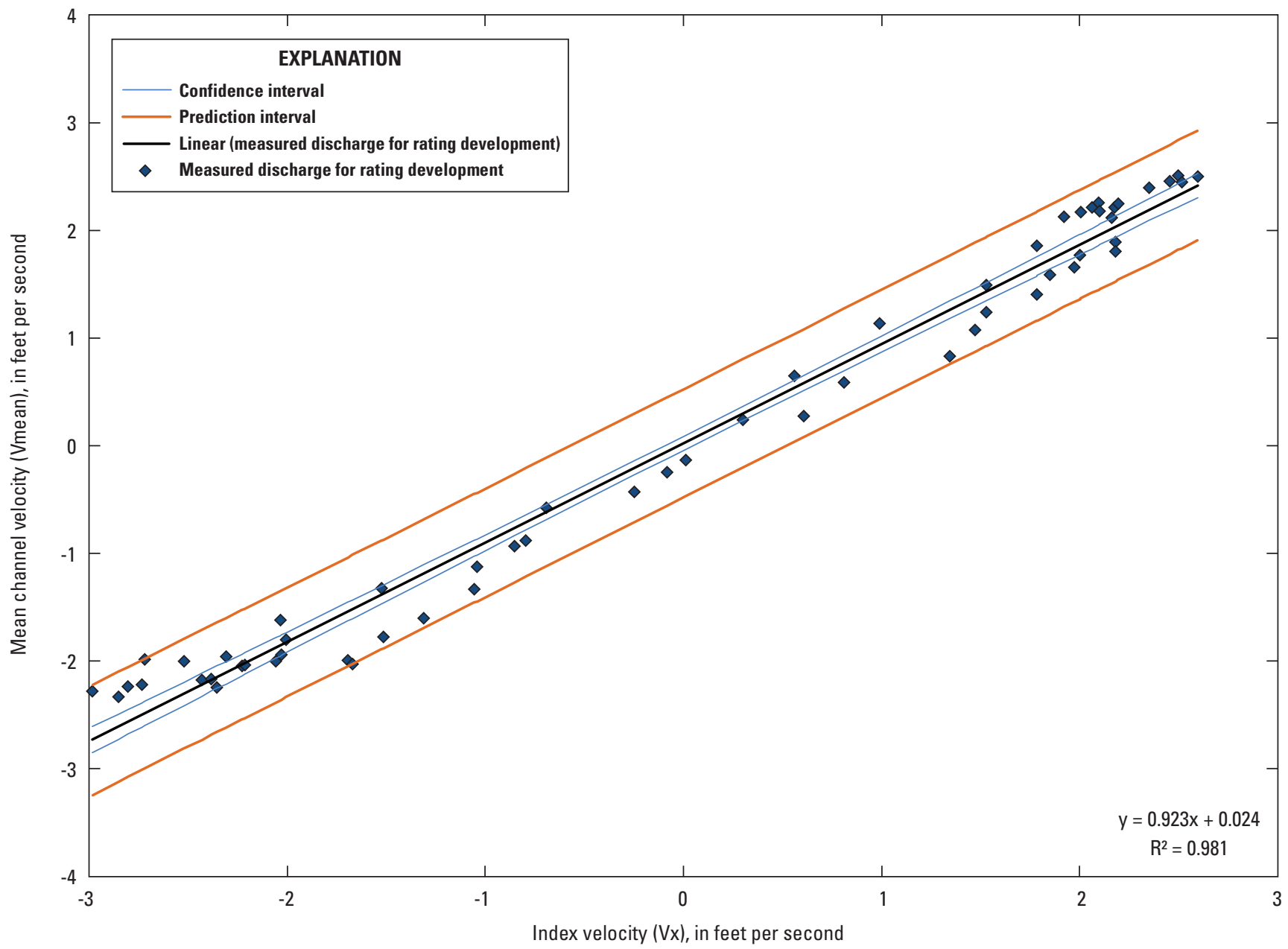

Figure 9. Index-velocity rating, determined by using simple linear regression, based on 58 discharge measurements made during March 2015 in Rockaway Inlet at Jamaica Bay, New York. $R^{2}$ is 0.981. 


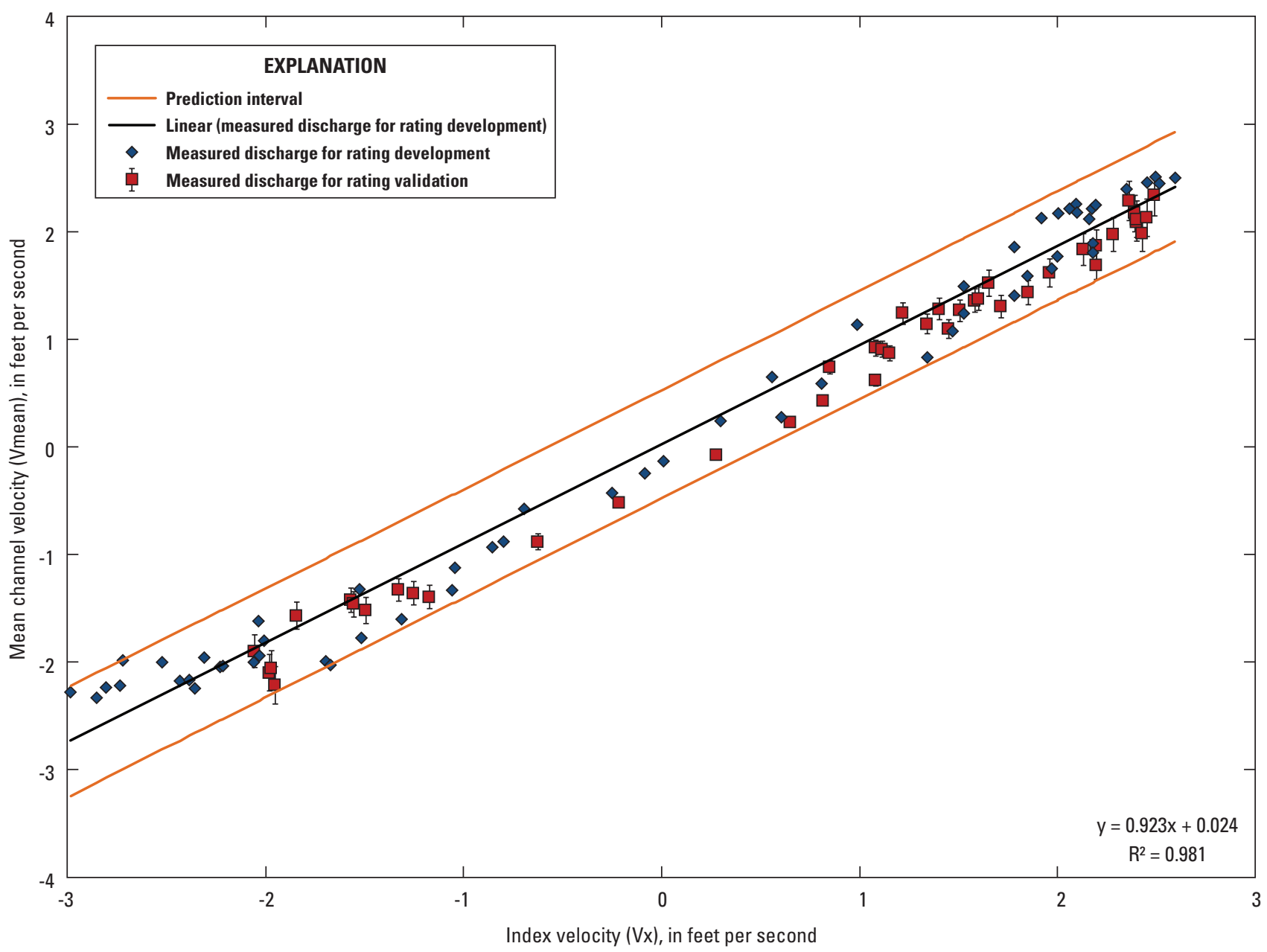

Figure 10. Validation of the index-velocity rating based on March 2015 measurements (fig. 9) by 43 validation discharge measurements made during 2015-16 in Rockaway Inlet at Jamaica Bay, New York. 


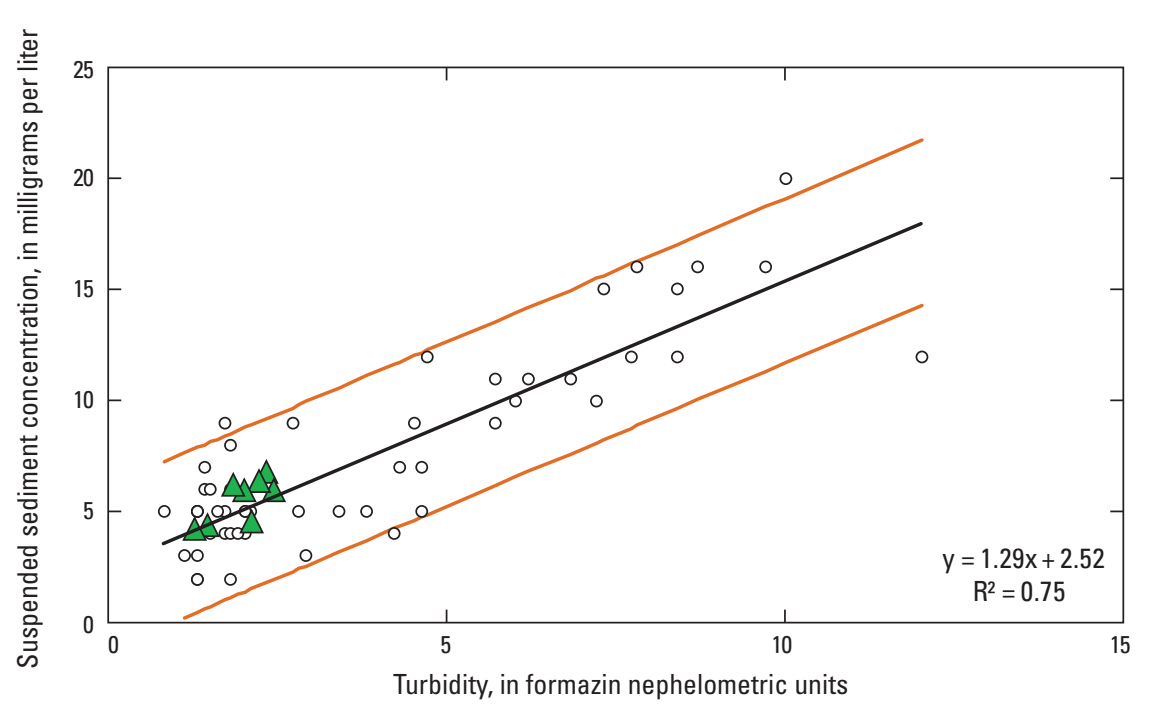

EXPLANATION

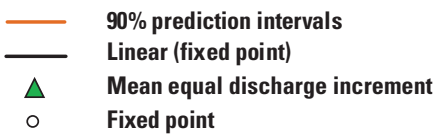

Figure 11. Relation between suspended-sediment concentration and turbidity derived from fixed-point data and compared to equal discharge increment data, 2015-16, at Rockaway Inlet at Jamaica Bay, New York.

Once the SSC and discharge were determined, the sediment flux was calculated by multiplication of the two parameters (Rasmussen and others, 2009, p. 22) and by conversion of units using AQUARIUS data management software (Aquatic Informatics Inc., 2018). Data from November 2014 to

December 2016 of suspended-sediment flux in pounds per second $(\mathrm{lb} / \mathrm{s})$ are plotted as suspended-sediment load in figure 12 .

Sediment loads during this period ranged from about $-450 \mathrm{lb} / \mathrm{s}$ (towards bay) to about $+350 \mathrm{lb} / \mathrm{s}$ (towards ocean).

\section{Discussion of Sediment Flux to Jamaica Bay: Role of Storms and Other Factors}

Although coastal storms are more commonly known as destructive, under certain conditions they can sustain or expand tidal marshes. Sediment resuspended by wind-driven waves can be transported onto marsh surfaces, especially to the high marsh during storm-surge conditions, thereby providing sediment needed for marsh health and possible accretion. Drivers include, but are not limited to, storm intensity, track, duration and seasonal timing, and marsh morphology.

Spring freshets (high-river-discharge events typically associated with icemelt or snowmelt and spring rains) can also supply sediment to a marsh system that is at or near the river's mouth. In the case of Jamaica Bay, the Hudson River is a potential source of sediment. The Hudson River discharges to the New York Harbor (and New York Bight) area (figs. 1 and 13) and can potentially deliver large volumes of sediment, especially during the spring freshet and during rain events farther to the north in the Hudson River drainage basin.

Under normal flow conditions, the Hudson River estuary tends to import sediment from the seaward direction, but sediment export is expected when spring tides coincide with strong river outflow, for example, during a freshet (Geyer and others, 2001). Under certain conditions, sediment provided by the Hudson River can also be transported towards Rockaway Inlet, at the northeast corner of the bight, and can be made available for transport into Jamaica Bay on incoming tides. Even if a strong freshet coincides with spring tide conditions, wind conditions can strongly affect the movement of the sediment-laden water and prevent it from moving into Jamaica Bay. Modeling results from Choi and Wilkin (2007) suggest that during steady river flow of relatively low volume, a sediment plume advances from the Hudson River estuary into the coastal ocean; upon entering the open shelf, the plume turns westward and flows predominantly along the New Jersey coast. However, northward winds tend to keep fresher (and potentially sediment-laden) water flowing toward the east from the New York Harbor. This eventually leads to a broad, lowsalinity area offshore from Long Island, which could potentially be available for transport into Jamaica Bay on flooding tides. For the November 2014 to December 2016 study period, 
USGS 01311875 ROCKAWAY INLET NEAR FLOYD BENNETT FIELD NY

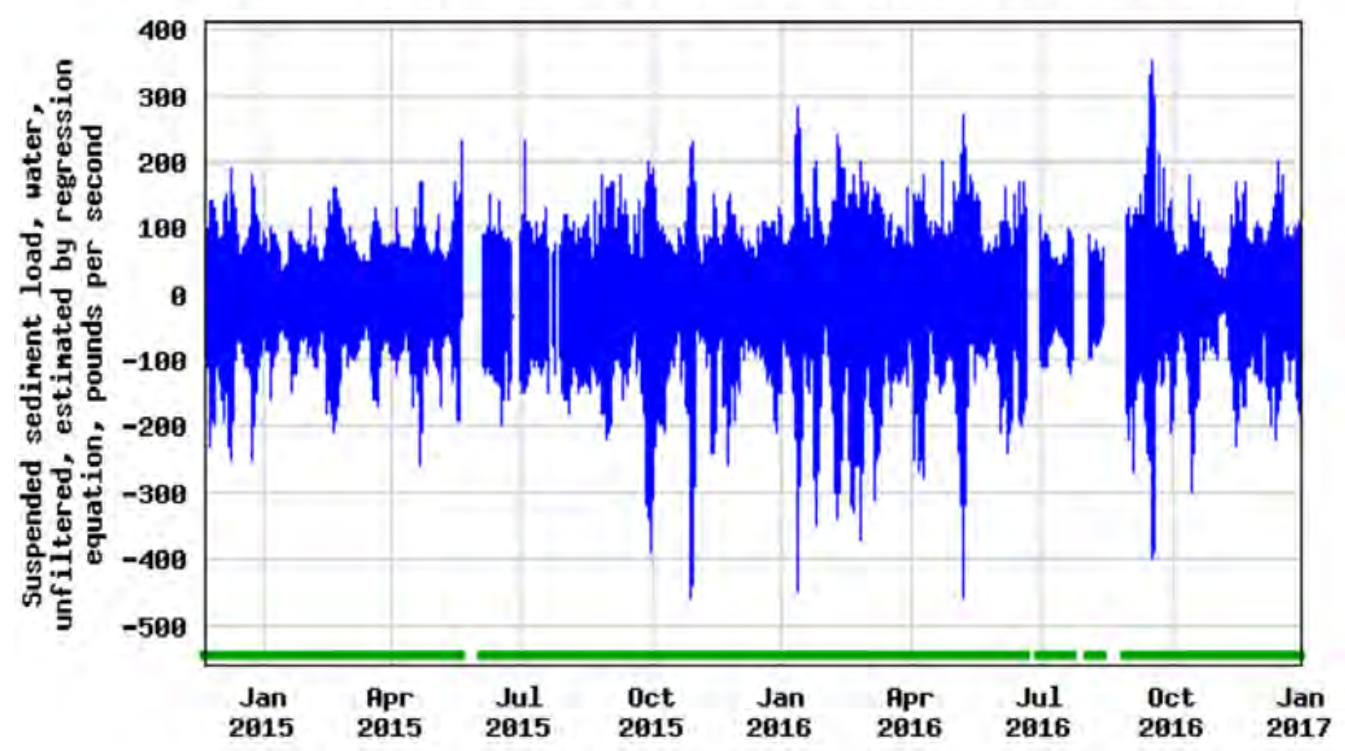

Figure 12. Suspended-sediment load at Rockaway Inlet at Jamaica Bay, New York, from November 2014 to December 2016. The graph is a screen capture of U.S. Geological Survey (USGS, 2017b) data output.

the highest turbidity event associated with a spring freshet at the USGS Hudson River station (01372058; USGS, 2019) did not cause a discernible increase of sediment flux at the Rockaway station (01311875). Other factors that may affect sediment redistribution in the tidal marsh are the many human activities in the marsh, including inlet and channel dredging, marsh-island restoration efforts, historical mosquito ditching, and boat wakes, to name a few. Dredging in the study area is generally focused on keeping navigable channels open but may be done in concert with marsh-island restoration efforts, whereby sediment from channels is pumped onto existing or artificial marsh islands. The effects of dredging and marsh restoration efforts on sediment flux in Jamaica Bay were not a focus of this investigation and cannot be evaluated without additional data collection.

\section{Examples of Sediment Flux from a Coastal Storm}

High winds, waves, and tidal surge associated with coastal storms typically cause resuspension of sediment. Figure 14 shows the increase in turbidity recorded at Rockaway Inlet associated with storm surge and winds from Hurricane Joaquin's track off the eastern seaboard during September and October 2015. Storm tide at Rockaway Inlet exceeded the National Weather Service minor coastal flood elevation (fig 14A) with a storm surge about 2 feet above predicted tidal elevations. Turbidity increased from a mean of about 2 FNU during September 22-24 (prior to Joaquin's approach) to a mean of about 7 FNU during highest winds and storm surge from October 1 to 3 (fig. 14B). Turbidity remained elevated for several tidal cycles as the storm passed and wind velocity diminished. The small gap in the turbidity record on September 24 represents a routine servicing when the monitor was out of the water for cleaning and calibration. This timely servicing provided a high level of confidence in the turbidity record during the following 2 weeks when water samples were collected for SSC analyses. Suspended-sediment concentrations from fixed-point water samples collected on September 28,2015 , and October 6,2015 , ranged from 3 to $16 \mathrm{mg} / \mathrm{L}$ and from 4 to $20 \mathrm{mg} / \mathrm{L}$, respectively, and correlate with the higher recorded turbidity values.

The suspended-sediment load through Rockaway Inlet (fig. 15) reflects the higher turbidities recorded at the tidegaging station during Hurricane Joaquin. Prestorm loads approached about $100 \mathrm{lb} / \mathrm{s}$, whereas loads were nearly $400 \mathrm{lb} / \mathrm{s}$ during and immediately after the storm. Sediment loads are often higher during incoming tides (negative loads on the $y$-axis) than during outgoing tides. Maximum suspendedsediment loads during the storm exceeded $400 \mathrm{lb} / \mathrm{s}$ during incoming tides but were only about $200 \mathrm{lb} / \mathrm{s}$ during outgoing tides. Figure 16 demonstrates this trend on a 2-day plot displaying tidal elevation and turbidity. The highest turbidities recorded were during the fastest velocities, which were typically during the later stages of the incoming tide. Higher sediment loads during incoming tides were also observed during nonstorm conditions. 


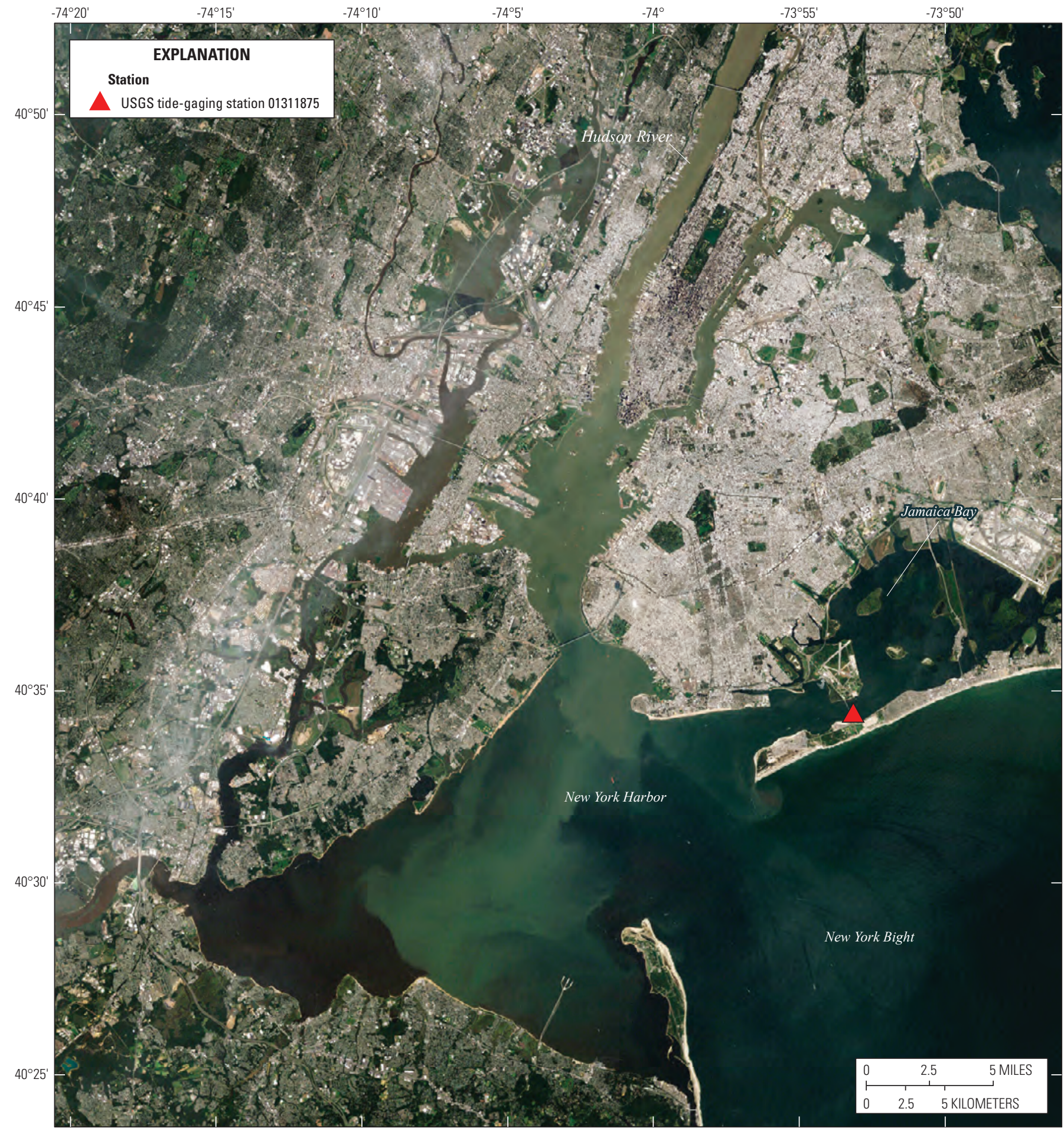

USGS/NASA Earth Observatory image by Robert Simmon, Landsat 5 data of August 31, 2011

WGS 1984 Web Mercator Auxiliary Sphere

Figure 13. New York metropolitan area and sediment-laden Hudson River discharging to New York Harbor (and New York Bight) after heavy rain associated with Hurricane Irene, August 31, 2011. U.S. Geological Survey (USGS)/National Aeronautics and Space Administration (NASA) Earth Observatory image by Robert Simmon, NASA. 
$\boldsymbol{A}$ ZUSGS

USGS 01311875 ROCKAWAY INLET NEAR FLOYD BENNETT FIELD NY

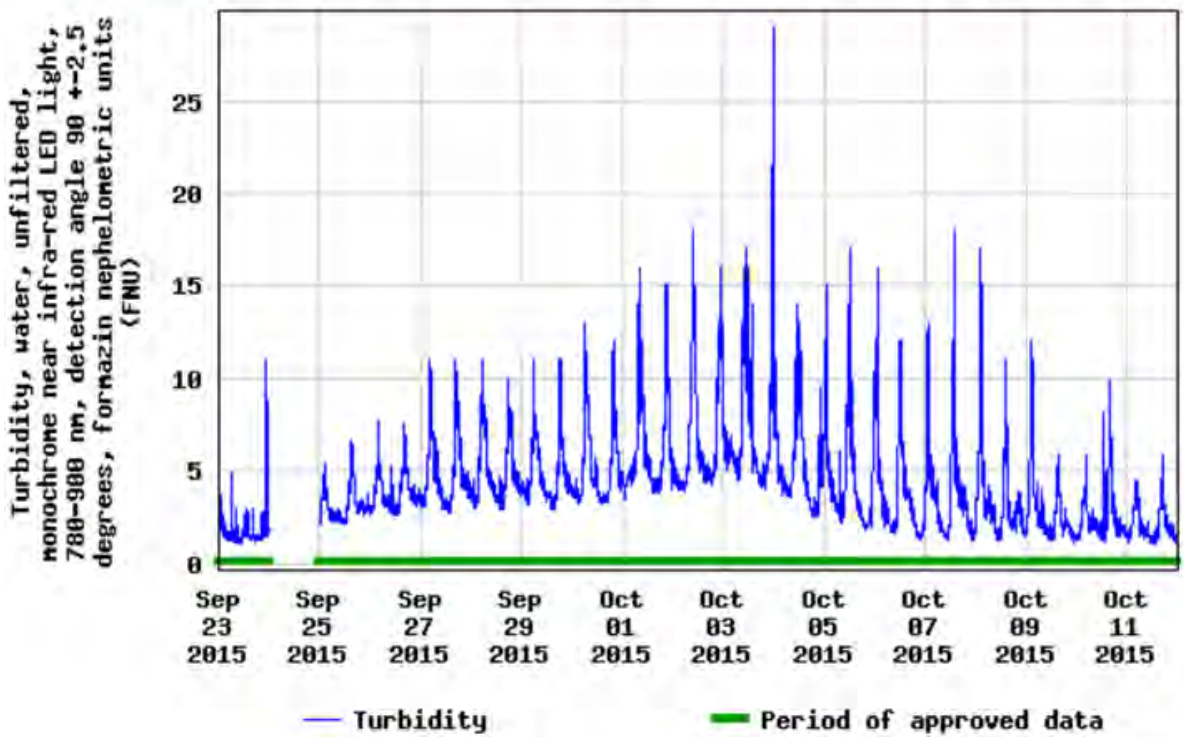

B

\section{ZUSES}

\section{USGS 01311875 ROCKAWAY INLET NEAR FLOYD BENNETT FIELD NY}

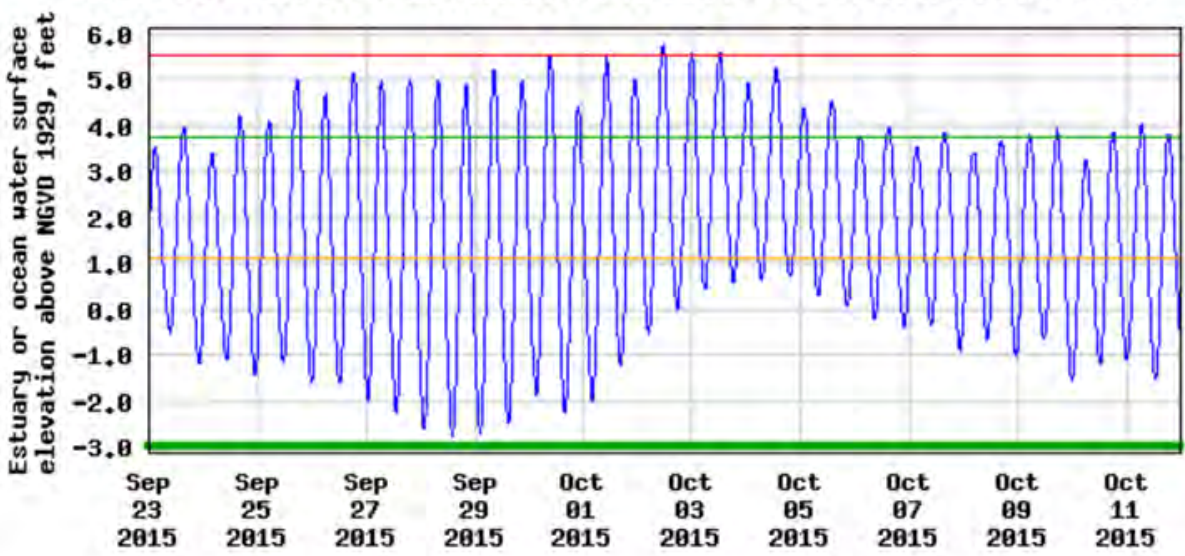

- Estuary or ocean water surface elevation above ngud 1929

- Period of approved data

- NHS Minor Coastal Flood Elevation

- Mean Higher High Mater

- North Anerican Vertical Datun of 1988

Figure 14. A, Estuary or ocean water-surface elevation and B, turbidity at Rockaway Inlet at Jamaica Bay, New York (U.S. Geological Survey [USGS] tide-gaging station 01311875) from September 23 to 0 ctober 11, 2015, during a period of high winds and minor coastal flooding associated with Hurricane Joaquin. The graphs are screen captures of USGS (2017b) data output. LED, light-emitting diode; NGVD, National Geodetic Vertical Datum; nm, nanometer; NWS, National Weather Service. 


\section{EUSGS}

USGS 01311875 ROCKAWAY INLET NEAR FLOYD BENNETT FIELD NY

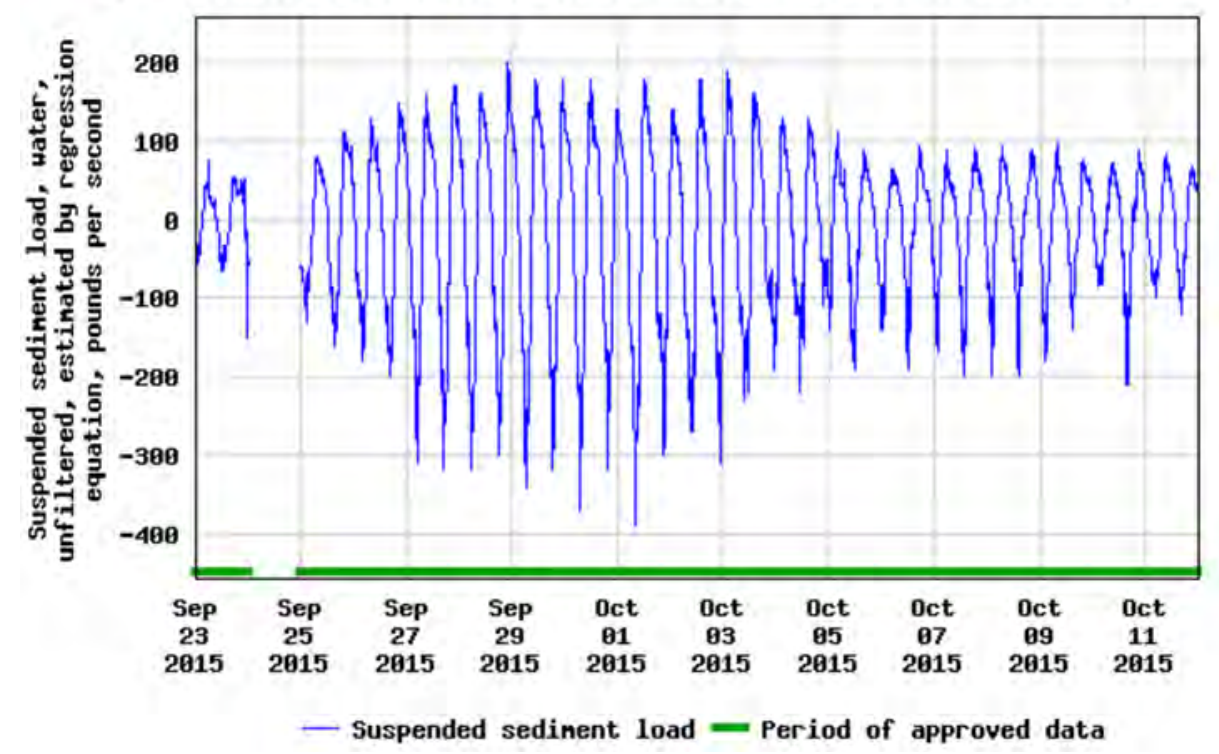

Figure 15. Suspended-sediment load at Rockaway Inlet at Jamaica Bay, New York (U.S. Geological Survey [USGS] tide-gaging station 01311875), from September 23 to October 11,2015 , spanning the period October 1-2, when Hurricane Joaquin passed off the eastern U.S. seaboard. The graph is a screen capture of USGS (2017b) data output. 
$\boldsymbol{A}$

\section{ZUSES}

USGS 01311875 ROCKAWAY INLET NEAR FLOYD BENNETT FIELD NY

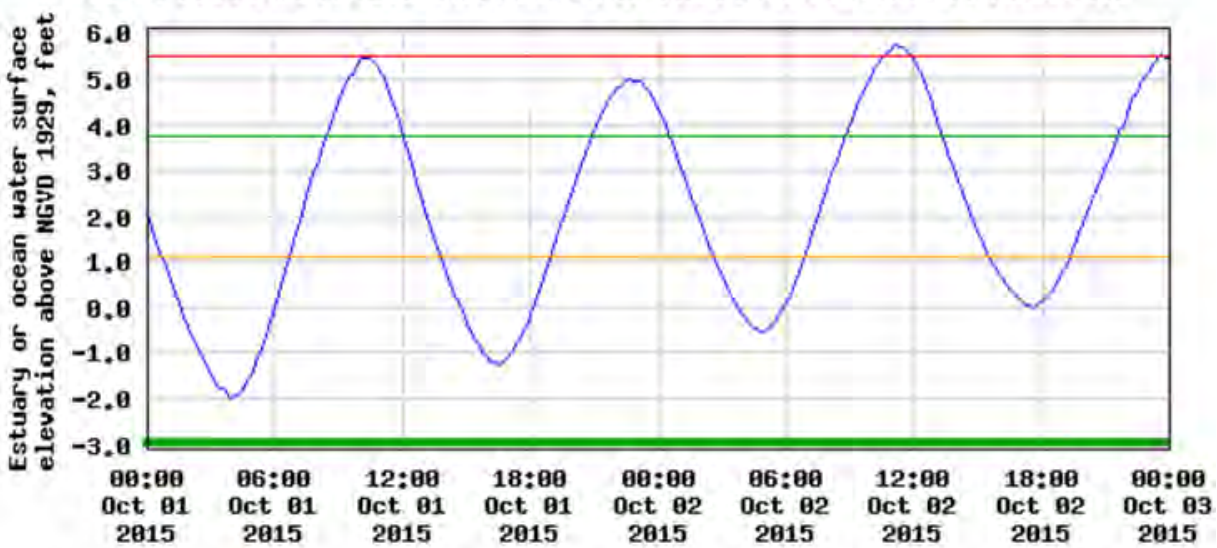

- Estuary or ocean water surface elevation above ngud 1929

- Period of approved data

- NHS Hinor Coastal Flood Elevation

- Mean Higher High Hater

North Anerican Vertical Datun of 1988

B ZUSGS

USGS 01311875 ROCKAWAY INLET NEAR FLOYD BENNETT FIELD NY

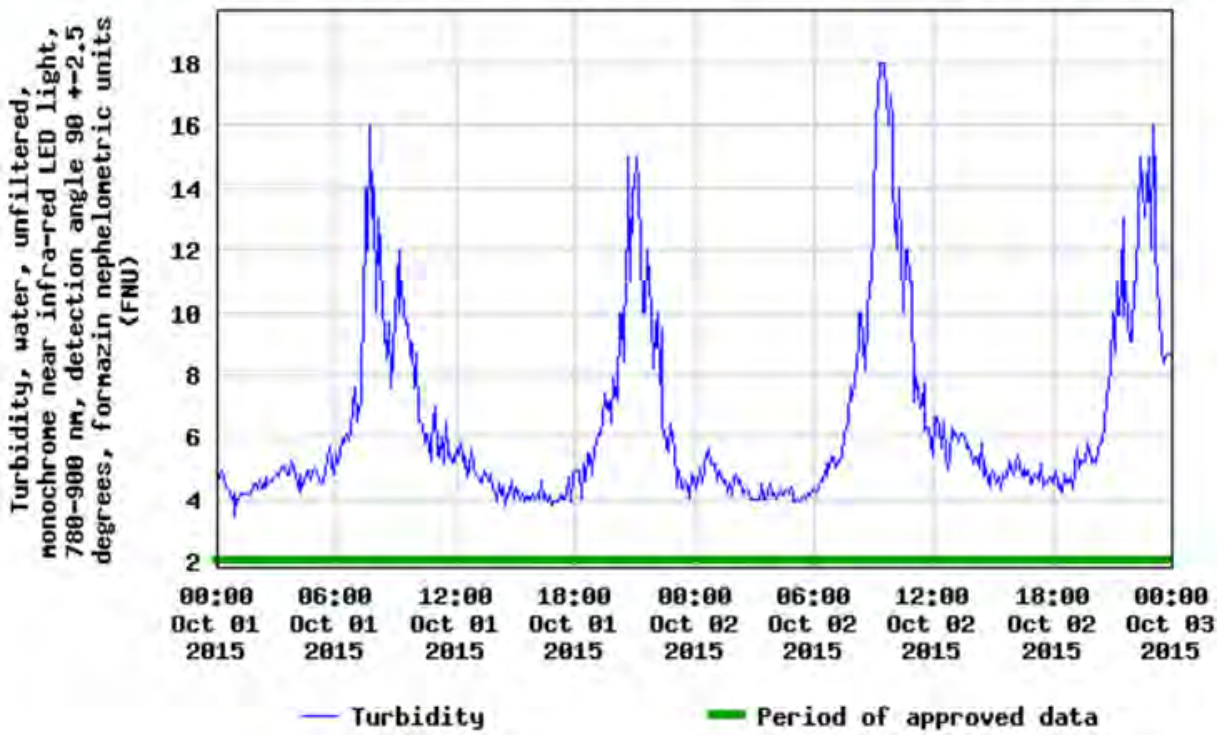

Figure 16. A, Tidal elevation and $B$, turbidity at Rockaway Inlet at Jamaica Bay, New York (U.S. Geological Survey [USGS] tide-gaging station 01311875), during October 1-2, 2015, while Hurricane Joaquin passed off the eastern U.S. seaboard. The graphs are screen captures of USGS (2017b) data output. LED, light-emitting diode; NGVD, National Geodetic Vertical Datum; nm, nanometer; NWS, National Weather Service. 


\section{Summary and Conclusions}

To estimate sediment flux in and out of Jamaica Bay, New York, through Rockaway Inlet, an index-velocity station and turbidity sensor were operated at the Marine Parkway-Gil Hodges Memorial Bridge from November 2014 to December 2016 and suspended-sediment samples were collected and analyzed between April 2015 and May 2016. Daily mean turbidity ranged from 0.6 to 8.2 formazin nephelometric units, and computed daily mean suspended-sediment concentrations ranged from 3 to 13 milligrams per liter. Two regressions were computed based on these data. First, continuous (6-minute) discharge was estimated by generating a simple linear regression $\left(\mathrm{R}^{2}\right.$ of 0.981$)$ between mean channel velocity measured from a boat-operated acoustic Doppler current profiler and range-averaged velocity measured at the acoustic Doppler velocity meter, and by then multiplying output from the stagearea and index-velocity relations. Second, suspended-sediment concentration was calculated from a simple linear regression $\left(\mathrm{R}^{2}\right.$ of 0.75$)$ of measured suspended-sediment concentration and turbidity at the index-velocity station.

These continuous data can be used in model design and calibration to help determine net sediment fluxes to the wetland complex and to evaluate depositional patterns as well as vulnerability of salt marsh shorelines to wave attack. During the study period from November 2014 to December 2016, calculated sediment fluxes in Rockaway Inlet at Jamaica Bay, N.Y., ranged from about -450 pounds per second (towards bay) to about +350 pounds per second (towards ocean). Sediment fluxes observed during this investigation varied with changing velocities associated with daily tidal cycles, as well as to spring and neap tides, but were generally higher during incoming tides than during outgoing tides. A major coastal storm hitting the Jamaica Bay area would likely have a major effect (export or import) on the sediment budget, so continued sediment monitoring is important.

\section{References Cited}

Aquatic Informatics Inc., 2018, AQUARIUS time-series [version 16]: Vancouver, British Columbia, Aquatic Informatics Inc. computer software, https://aquaticinformatics.com/ products/aquarius-time-series/.

Choi, B.-J., and Wilkin, J.L., 2007, The effect of wind on the dispersal of the Hudson river plume: Journal of Physical Oceanography, v. 37, no. 7, p. 1878-1897. [Also available at https://doi.org/10.1175/JPO3081.1.]

Dahl, T.E., and Stedman, S.M., 2013, Status and trends of wetlands in the coastal watersheds of the conterminous United States-2004 to 2009: U.S. Fish and Wildlife Service and National Oceanic and Atmospheric Administration, National Marine Fisheries Service, 46 p.
Domanski, M.M., Straub, T.D., and Landers, M.N., 2015, Surrogate Analysis and Index Developer (SAID) tool (version 1.0, September 2015): U.S. Geological Survey OpenFile Report 2015-1177, 38 p., accessed March 8, 2017, at http://dx.doi.org/10.3133/ofr20151177.

Geyer, W.R., Woodruff, J.D., and Traykovski, P., 2001, Sediment transport and trapping in the Hudson River estuary: Estuaries, v. 24, no. 5, p. 670-679. [Also available at https://doi.org/10.2307/1352875.]

Godin, G., 1972, The analysis of tides: Toronto, University of Toronto Press, 264 p.

Hartig, E.K., Gornitz, V., Kolker, A., Mushacke, F., and Fallon, D., 2002, Anthropogenic and climate-change impacts on salt marshes of Jamaica Bay, New York City: Wetlands, v. 22, no. 1, p. 71-89. [Also available at https://doi.org/10.1672/0277-5212(2002)022

[0071:AACCIO]2.0.CO;2.]

Levesque, V.A., and Oberg, K.A., 2012, Computing discharge using the index velocity method: U.S. Geological Survey Techniques and Methods, book 3, chap. A23, 148 p., accessed January 15, 2014, at https://pubs.usgs.gov/ $\mathrm{tm} / 3 \mathrm{a} 23 /$.

Mueller, D.S., Wagner, C.R., 2009, Measuring discharge with acoustic Doppler current profilers from a moving boat: U.S. Geological Survey Techniques and Methods, book 3, chap. A22, 72 p. [Also available at https://dx.doi.org/10.3133/tm3A22.]

New York City Department of Environmental Protection, 2007, Jamaica Bay Watershed Protection Plan, volume I-The plan: New York State Department of Environmental Conservation web page, accessed June 2, 2007, at http://www.nyc.gov/html/dep/html/dep_projects/ jamaica_bay.shtml.

New York State Department of Environmental Conservation [NYSDEC], 2001, Tidal wetlands losses, Jamaica Bay, Queens County, NY: New York State Department of Environmental Conservation web page, accessed July 23, 2007, at http://www.dec.ny.gov/lands/5489.html.

Rasmussen, P.P., Gray, J.R., Glysson, G.D., and Ziegler, A.C., 2009, Guidelines and procedures for computing time-series suspended-sediment concentrations and loads from instream turbidity-sensor and streamflow data: U.S. Geological Survey Techniques and Methods, book 3, chap. C4, $52 \mathrm{p}$. [Also available at https://pubs.usgs.gov/tm/tm3c4/.]

Riggs, H.C., 1968, Some statistical tools in hydrology: U.S. Geological Survey Techniques of Water-Resources Investigations, book 4, chap. A1, 39 p. [Also available at https://pubs.er.usgs.gov/publication/twri04A1.] 
Ruhl, C.A., and Simpson, M.R., 2005, Computation of discharge using the index-velocity method in tidally affected areas: U.S. Geological Survey Scientific Investigations Report 2005-5004, 31 p., accessed January 24, 2014, at https://pubs.er.usgs.gov/publication/sir20055004.

Schubert, C.E., Busciolano, R., Hearn, P.P., Jr., Rahav, A.N., Behrens, R., Finkelstein, J., Monti, J., Jr., and Simonson, A.E., 2015, Analysis of storm-tide impacts from Hurricane Sandy in New York: U.S. Geological Survey Scientific Investigations Report 2015-5036, 75 p. [Also available at http://dx.doi.org/10.3133/sir20155036.]

Shreve, E.A., and Downs, A.C., 2005, Quality-assurance plan for the analysis of fluvial sediment by the U.S. Geological Survey Kentucky Water Science Center Sediment Laboratory: U.S. Geological Survey Open-File Report 2005-1230, 28 p., accessed June 14, 2017, at https://pubs.er.usgs.gov/ publication/ofr20051230.

U.S. Geological Survey [USGS], 2004, Quality-control of water-quality samples: U.S. Geological Survey web page, accessed July 30, 2018, at https://pubs.usgs.gov/wdr/2004/ wdr-il-04/misc/qcofples.htm.

U.S. Geological Survey [USGS], 2011, Processing and publication of discharge and stage data collected in tidallyinfluenced areas: U.S. Geological Survey Office of Surface Water Technical Memorandum 2010.08, 38 p., accessed January 13, 2016, at https:/water.usgs.gov/admin/memo/ SW/sw10.08-final_tidal_policy_memo.pdf.

U.S. Geological Survey [USGS], 2015, AreaComp: U.S. Geological Survey web page, accessed July 6, 2018, at https://hydroacoustics.usgs.gov/indexvelocity/ AreaComp.shtml.
U.S. Geological Survey [USGS], 2017a, Policy and guidance for shifting and check measurement practices when using the index-velocity method: U.S. Geological Survey Office of Surface Water Technical Memorandum 2017.03, accessed May 15, 2018, at https://water.usgs.gov/admin/ memo/SW/sw17.03-attachments.pdf

U.S. Geological Survey [USGS], 2017b, USGS 01311875 Rockaway Inlet near Floyd Bennet Field NY, in USGS Water Data for the Nation: U.S. Geological Survey National Water Information System database, accessed March 28, 2017, at http://dx.doi.org/10.5066/F7P55KJN. [Site information directly accessible at https://waterdata.usgs.gov/ny/ nwis/inventory/?site_no $=01311875$.]

U.S. Geological Survey [USGS], 2019, USGS 01372058 Hudson River below Poughkeepsie NY, in USGS Water Data for the Nation: U.S. Geological Survey National Water Information System database, accessed May 20, 2019, at http://dx.doi.org/10.5066/F7P55KJN. [Site information directly accessible at https://waterdata.usgs.gov/ny/nwis/ inventory/?site_no $=01372058$.]

U.S. Geological Survey [USGS], variously dated, The national field manual for the collection of water-quality data: U.S. Geological Survey Techniques and Methods, book 9, chaps. A1-A10, accessed April 5, 2013, at http://water.usgs.gov/owq/FieldManual/.

Wagner, R.J., Boulger, R.W., Jr., Oblinger, C.J., and Smith, B.A., 2006, Guidelines and standard procedures for continuous water-quality monitors - Station operation, record computation, and data reporting: U.S. Geological Survey Techniques and Methods, book 1, chap D3, 51 p., 8 attachments, accessed November 12, 2010, at http://pubs.water.usgs.gov/tm1d3. 



\section{Appendix 1. Data Tables and Statistics for Stage-Area, Index-Velocity, and Turbidity-Suspended-Sediment-Concentration Ratings for U.S. Geological Survey Tide-Gaging Station 01311875, Rockaway Inlet at Floyd Bennett Field, New York}

Table 1.1. Stage-area rating data for U.S. Geological Survey tide-gaging station 01311875, Rockaway Inlet at Floyd Bennett Field, New York.

[Rating developed using the U.S. Geological Survey program AreaComp2, version 1.06. Approximate location of standard cross section is 200 feet east of gage; latitude $40^{\circ} 34^{\prime} 25^{\prime \prime}$, longitude 735' $08^{\prime \prime}$ North American Datum of 1927; datum of gage: 0 feet above National Geodetic Vertical Datum of 1929]

\begin{tabular}{cc}
\hline Stage (feet) & Area (square feet) \\
\hline-6.0 & $97,134.8$ \\
-5.5 & $98,947.4$ \\
-5.0 & $100,763.4$ \\
-4.5 & $102,582.7$ \\
-4.0 & $104,405.4$ \\
-3.5 & $106,231.5$ \\
-3.0 & $108,060.9$ \\
-2.5 & $109,893.8$ \\
-2.0 & $111,730.0$ \\
-1.5 & $113,569.6$ \\
-1.0 & $115,412.5$ \\
-0.5 & $117,258.0$ \\
0.0 & $119,106.0$ \\
0.5 & $120,956.2$ \\
1.0 & $122,808.7$ \\
1.5 & $124,663.6$ \\
2.0 & $126,520.7$ \\
2.5 & $128,380.2$ \\
3.0 & $130,242.0$
\end{tabular}

Table 1.1. Stage-area rating data for U.S. Geological Survey tide-gaging station 01311875, Rockaway Inlet at Floyd Bennett Field, New York.-Continued

[Rating developed using the U.S. Geological Survey program AreaComp2, version 1.06. Approximate location of standard cross section is 200 feet east of gage; latitude $40^{\circ} 34^{\prime} 25^{\prime \prime}$, longitude $73^{\circ} 53^{\prime} 08^{\prime \prime}$ North American Datum of 1927; datum of gage: 0 feet above National Geodetic Vertical Datum of 1929]

\begin{tabular}{cc}
\hline Stage (feet) & Area (square feet) \\
\hline 3.5 & $132,106.1$ \\
4.0 & $133,972.5$ \\
4.5 & $135,841.2$ \\
5.0 & $137,718.1$ \\
5.5 & $139,599.0$ \\
6.0 & $141,483.8$ \\
6.5 & $143,376.8$ \\
7.0 & $145,343.6$ \\
7.5 & $147,327.1$ \\
8.0 & $149,326.7$ \\
8.5 & $151,342.2$ \\
9.0 & $153,371.8$ \\
9.5 & $155,414.4$ \\
10.0 & $157,469.8$ \\
10.5 & $159,538.0$ \\
11.0 & $161,619.1$ \\
11.5 & $163,713.1$ \\
12.0 & $165,819.2$ \\
\hline
\end{tabular}


Table 1.2. Index-velocity rating data for U.S. Geological Survey tide-gaging station 01311875, Rockaway Inlet at Floyd Bennett Field, New York.

[Discharge measurements used for rating analysis and correlated with acoustic Doppler velocity meter (ADVM)-observed data to develop an index-velocity rating (fig. 9). mm/dd/yyyy hh:mm:ss, month/date, year, hour, minute, second, in Eastern Standard Time; Q, discharge; A, area; Vi, average index velocity measured by the ADVM, in feet per second; Vx, velocity in the $\mathrm{x}$ direction (perpendicular to the instrument)]

\begin{tabular}{|c|c|c|c|c|c|c|c|}
\hline $\begin{array}{l}\text { Measure- } \\
\text { ment } \\
\text { number }\end{array}$ & $\begin{array}{l}\text { Date/time of measurement } \\
\text { (mm/dd/yyyy hh:mm:ss) }\end{array}$ & $\begin{array}{l}\text { Measured } \\
\text { discharge } \\
\text { (cubic feet } \\
\text { per second) }\end{array}$ & $\begin{array}{l}\text { Mean channel ve- } \\
\text { locity }(0 / \text { rated } A) \\
\text { (feet per second) }\end{array}$ & $\begin{array}{l}\text { Stage } \\
\text { (feet) }\end{array}$ & $\begin{array}{c}\text { Vi } \\
\text { (feet per } \\
\text { second) }\end{array}$ & $\begin{array}{l}\text { Vi } \times \text { Stage } \\
\text { (square feet } \\
\text { per second) }\end{array}$ & $\begin{array}{c}\text { Range aver- } \\
\text { aged cell (Vx) } \\
\text { (feet per } \\
\text { second) }\end{array}$ \\
\hline 15 & 03/21/2015 10:04:09 & 317,000 & 2.400 & 3.51 & 2.35 & 8.25 & 2.35 \\
\hline 16 & 03/21/2015 10:30:18 & 324,000 & 2.506 & 2.76 & 2.59 & 7.15 & 2.59 \\
\hline 17 & 03/21/2015 10:42:41 & 322,000 & 2.516 & 2.39 & 2.49 & 5.96 & 2.49 \\
\hline 18 & 03/21/2015 11:05:52 & 307,000 & 2.450 & 1.67 & 2.51 & 4.20 & 2.51 \\
\hline 19 & 03/21/2015 11:18:21 & 305,000 & 2.464 & 1.28 & 2.45 & 3.14 & 2.45 \\
\hline 20 & $03 / 21 / 2015$ 12:18:24 & 260,000 & 2.217 & -0.36 & 2.17 & -0.78 & 2.17 \\
\hline 21 & $03 / 21 / 201512: 36: 25$ & 246,000 & 2.124 & -0.81 & 2.16 & -1.75 & 2.16 \\
\hline 22 & 03/21/2015 13:06:33 & 201,000 & 1.769 & -1.43 & 2.00 & -2.86 & 2.00 \\
\hline 23 & 03/21/2015 13:30:27 & 186,000 & 1.664 & -1.91 & 1.97 & -3.76 & 1.97 \\
\hline 24 & 03/21/2015 13:42:18 & 177,000 & 1.595 & -2.12 & 1.85 & -3.92 & 1.85 \\
\hline 25 & 03/21/2015 13:54:12 & 156,000 & 1.409 & -2.28 & 1.78 & -4.06 & 1.78 \\
\hline 26 & 03/21/2015 14:06:28 & 137,000 & 1.247 & -2.43 & 1.53 & -3.71 & 1.53 \\
\hline 27 & 03/21/2015 14:18:28 & 118,000 & 1.077 & -2.54 & 1.47 & -3.74 & 1.47 \\
\hline 28 & 03/21/2015 14:30:36 & 91,600 & 0.839 & -2.62 & 1.34 & -3.52 & 1.34 \\
\hline 29 & 03/21/2015 14:42:08 & 64,500 & 0.591 & -2.65 & 0.81 & -2.14 & 0.81 \\
\hline 30 & 03/21/2015 14:54:09 & 30,000 & 0.275 & -2.61 & 0.61 & -1.58 & 0.61 \\
\hline 31 & $03 / 21 / 2015$ 15:05:60 & $-14,000$ & -0.128 & -2.55 & 0.01 & -0.03 & 0.01 \\
\hline 32 & 03/21/2015 15:17:54 & $-46,800$ & -0.426 & -2.42 & -0.25 & 0.60 & -0.25 \\
\hline 33 & 03/21/2015 15:30:06 & $-103,000$ & -0.930 & -2.25 & -0.85 & 1.92 & -0.85 \\
\hline 34 & $03 / 21 / 201515: 42: 53$ & $-147,000$ & -1.320 & -2.05 & -1.53 & 3.13 & -1.53 \\
\hline 35 & 03/21/2015 15:54:50 & $-181,000$ & -1.615 & -1.83 & -2.04 & 3.73 & -2.04 \\
\hline 36 & 03/21/2015 16:06:17 & $-203,000$ & -1.798 & -1.57 & -2.01 & 3.15 & -2.01 \\
\hline 37 & $03 / 21 / 201516: 17: 56$ & $-221,000$ & -1.937 & -1.36 & -2.03 & 2.76 & -2.03 \\
\hline 38 & 03/21/2015 16:29:47 & $-234,000$ & -2.040 & -1.06 & -2.23 & 2.36 & -2.23 \\
\hline 39 & 03/21/2015 16:42:15 & $-237,000$ & -2.036 & -0.74 & -2.22 & 1.64 & -2.22 \\
\hline 40 & $03 / 21 / 201516: 54: 41$ & $-254,000$ & -2.165 & -0.42 & -2.38 & 1.00 & -2.38 \\
\hline 41 & 03/21/2015 17:06:06 & $-257,000$ & -2.171 & -0.09 & -2.43 & 0.22 & -2.43 \\
\hline 42 & 03/21/2015 17:18:37 & $-266,000$ & -2.219 & 0.22 & -2.74 & -0.60 & -2.74 \\
\hline 43 & $03 / 21 / 201517: 35: 34$ & $-272,000$ & -2.235 & 0.70 & -2.80 & -1.96 & -2.80 \\
\hline 44 & 03/21/2015 17:48:16 & $-276,000$ & -2.244 & 1.05 & -2.36 & -2.47 & -2.36 \\
\hline 45 & 03/21/2015 18:00:23 & $-289,000$ & -2.327 & 1.38 & -2.85 & -3.94 & -2.85 \\
\hline 46 & 03/21/2015 18:12:21 & $-285,000$ & -2.273 & 1.69 & -2.98 & -5.04 & -2.98 \\
\hline 47 & 03/23/2015 07:42:04 & $-235,000$ & -1.953 & 0.31 & -2.31 & -0.72 & -2.31 \\
\hline 48 & 03/23/2015 07:54:26 & $-242,000$ & -1.995 & 0.59 & -2.52 & -1.49 & -2.52 \\
\hline 49 & 03/23/2015 08:06:26 & $-242,000$ & -1.979 & 0.86 & -2.72 & -2.34 & -2.72 \\
\hline 50 & 03/23/2015 08:18:51 & $-247,000$ & -2.000 & 1.19 & -2.06 & -2.45 & -2.06 \\
\hline 51 & 03/23/2015 08:30:22 & $-252,000$ & -2.024 & 1.47 & -1.67 & -2.46 & -1.67 \\
\hline 52 & 03/23/2015 08:42:27 & $-250,000$ & -1.990 & 1.75 & -1.69 & -2.97 & -1.69 \\
\hline
\end{tabular}


Table 1.2. Index-velocity rating data for U.S. Geological Survey tide-gaging station 01311875, Rockaway Inlet at Floyd Bennett Field, New York.-Continued

[Discharge measurements used for rating analysis and correlated with acoustic Doppler velocity meter (ADVM)-observed data to develop an index-velocity rating (fig. 9). mm/dd/yyyy hh:mm:ss, month/date, year, hour, minute, second, in Eastern Standard Time; Q, discharge; A, area; Vi, average index velocity measured by the ADVM, in feet per second; $\mathrm{Vx}$, velocity in the $\mathrm{x}$ direction (perpendicular to the instrument)]

\begin{tabular}{cccccccc}
\hline $\begin{array}{c}\text { Measure- } \\
\text { ment } \\
\text { number }\end{array}$ & $\begin{array}{c}\text { Date/time of measurement } \\
\text { (mm/dd/yyy hh:mm:ss) }\end{array}$ & $\begin{array}{c}\text { Measured } \\
\text { discharge } \\
\text { (cubic feet } \\
\text { per second) }\end{array}$ & $\begin{array}{c}\text { Mean channel ve- } \\
\text { locity (Q/rated A) } \\
\text { (feet per second) }\end{array}$ & $\begin{array}{c}\text { Stage } \\
\text { (feet) }\end{array}$ & $\begin{array}{c}\text { Vi } \\
\text { (feet per } \\
\text { second) }\end{array}$ & $\begin{array}{c}\text { Vi } \times \text { Stage } \\
\text { (square feet } \\
\text { per second) }\end{array}$ & $\begin{array}{c}\text { Range aver- } \\
\text { aged cell (Vx) } \\
\text { (feet per } \\
\text { second) }\end{array}$ \\
\hline 53 & $03 / 23 / 201509: 06: 16$ & $-226,000$ & -1.773 & 2.26 & -1.52 & -3.43 & -1.52 \\
54 & $03 / 23 / 201509: 18: 22$ & $-205,000$ & -1.598 & 2.48 & -1.31 & -3.25 & -1.31 \\
55 & $03 / 23 / 201509: 36: 07$ & $-172,000$ & -1.330 & 2.76 & -1.06 & -2.93 & -1.06 \\
56 & $03 / 23 / 201509: 48: 24$ & $-146,000$ & -1.124 & 2.90 & -1.04 & -3.03 & -1.04 \\
57 & $03 / 23 / 201510: 00: 25$ & $-114,000$ & -0.876 & 3.00 & -0.80 & -2.39 & -0.80 \\
58 & $03 / 23 / 201510: 12: 17$ & $-75,100$ & -0.575 & 3.07 & -0.69 & -2.12 & -0.69 \\
59 & $03 / 23 / 201510: 24: 48$ & $-31,200$ & -0.239 & 3.07 & -0.09 & -0.27 & -0.09 \\
60 & $03 / 23 / 201510: 37: 04$ & 31,800 & 0.244 & 2.98 & 0.30 & 0.88 & 0.30 \\
61 & $03 / 23 / 201510: 48: 35$ & 84,500 & 0.651 & 2.87 & 0.56 & 1.60 & 0.56 \\
62 & $03 / 23 / 201511: 00: 08$ & 147,000 & 1.140 & 2.68 & 0.99 & 2.65 & 0.99 \\
63 & $03 / 23 / 201511: 11: 43$ & 192,000 & 1.496 & 2.49 & 1.53 & 3.80 & 1.53 \\
64 & $03 / 23 / 201511: 23: 58$ & 237,000 & 1.863 & 2.18 & 1.78 & 3.88 & 1.78 \\
65 & $03 / 23 / 201511: 36: 17$ & 269,000 & 2.133 & 1.89 & 1.92 & 3.62 & 1.92 \\
66 & $03 / 23 / 201511: 47: 59$ & 273,000 & 2.182 & 1.62 & 2.10 & 3.40 & 2.10 \\
67 & $03 / 23 / 201512: 00: 09$ & 279,000 & 2.252 & 1.30 & 2.19 & 2.85 & 2.19 \\
68 & $03 / 23 / 201512: 12: 31$ & 278,000 & 2.264 & 1.00 & 2.09 & 2.09 & 2.09 \\
69 & $03 / 23 / 201512: 24: 05$ & 270,000 & 2.219 & 0.71 & 2.06 & 1.46 & 2.06 \\
70 & $03 / 23 / 201512: 36: 27$ & 262,000 & 2.172 & 0.41 & 2.00 & 0.82 & 2.00 \\
71 & $03 / 23 / 201513: 53: 47$ & 215,000 & 1.899 & -1.49 & 2.18 & -3.25 & 2.18 \\
72 & $03 / 23 / 201514: 06: 33$ & 203,000 & 1.804 & -1.75 & 2.18 & -3.81 & 2.18 \\
\hline
\end{tabular}


Table 1.3. Suspended-sediment concentrations and turbidity rating data for U.S. Geological Survey tide-gaging station 01311875, Rockaway Inlet at Floyd Bennett Field, New York.

[Suspended-sediment concentrations (SSC) used for simple linear regression (fig. 11) between fixed-point SSC and turbidity and the 90-percent prediction interval, and the mean equal discharge increment (EDI) SSC data. mm/dd/yyyy hh:mm:ss, month/date, year, hour, minute, second, in Eastern Standard Time; Q, discharge; SSC, suspended-sediment concentration; SSL, suspended-sediment load; NA, not applicable]

\begin{tabular}{|c|c|c|c|c|c|c|c|c|}
\hline Sample type & $\begin{array}{c}\text { Date and time } \\
\text { (mm/dd/yyyy } \\
\text { hh:mm:ss) }\end{array}$ & $\begin{array}{l}\text { Turbidity } \\
\text { (formazin } \\
\text { nephelomet- } \\
\text { ric units) }\end{array}$ & $\begin{array}{c}0 \\
\text { (cubic feet } \\
\text { per second) }\end{array}$ & $\begin{array}{c}\text { SSC } \\
\text { (milli- } \\
\text { grams per } \\
\text { liter) }\end{array}$ & $\begin{array}{c}\text { SSL } \\
\text { (pounds } \\
\text { per } \\
\text { second) }\end{array}$ & $\begin{array}{l}\text { Regression- } \\
\text { computed } \\
\text { SSC } \\
\text { (milligrams } \\
\text { per liter) }\end{array}$ & $\begin{array}{l}\text { Residual } \\
\text { SSC }\end{array}$ & $\begin{array}{c}\text { Normal } \\
\text { quantiles }\end{array}$ \\
\hline Fixed point & $9 / 28 / 2015$ 15:00 & 2.9 & 853,000 & 3 & 159.7 & 6.262 & -3.262 & -1.473 \\
\hline Fixed point & $9 / 28 / 2015$ 15:30 & 3.4 & 791,000 & 5 & 246.8 & 6.908 & -1.908 & -0.962 \\
\hline Fixed point & 9/28/2015 16:00 & 4.3 & 748,000 & 7 & 326.7 & 8.07 & -1.07 & -0.511 \\
\hline Fixed point & $9 / 28 / 201516: 30$ & 4.7 & 727,000 & 12 & 544.4 & 8.586 & 3.414 & 1.637 \\
\hline Fixed point & 9/28/2015 17:00 & 6.2 & 707,000 & 11 & 485.3 & 10.52 & 0.477 & 0.247 \\
\hline Fixed point & $9 / 28 / 2015$ 17:30 & 8.7 & 707,000 & 16 & 705.9 & 13.75 & 2.249 & 0.962 \\
\hline Fixed point & 9/28/2015 18:00 & 7.2 & 697,000 & 10 & 434.9 & 11.81 & -1.814 & -0.887 \\
\hline Fixed point & 9/28/2015 18:12 & 6.8 & 681,000 & 11 & 467.4 & 11.3 & -0.298 & -0.098 \\
\hline Fixed point & 9/28/2015 18:30 & 7.8 & 687,000 & 16 & 685.9 & 12.59 & 3.411 & 1.473 \\
\hline Fixed point & 9/28/2015 19:00 & 8.4 & 715,000 & 12 & 535.4 & 13.36 & -1.364 & -0.750 \\
\hline Fixed point & 9/28/2015 19:30 & 5.7 & 778,000 & 9 & 436.9 & 9.877 & -0.878 & -0.350 \\
\hline Fixed point & 9/28/2015 20:00 & 4.5 & 883,000 & 9 & 495.9 & 8.328 & 0.672 & 0.298 \\
\hline Fixed point & 10/6/2015 9:30 & 1.7 & 945,700 & 4 & 236 & 4.713 & -0.713 & -0.247 \\
\hline Fixed point & 10/6/2015 10:00 & 2 & 844,000 & 4 & 210.7 & 5.1 & -1.1 & -0.568 \\
\hline Fixed point & $10 / 6 / 201510: 30$ & 2.8 & 815,000 & 5 & 254.3 & 6.133 & -1.133 & -0.626 \\
\hline Fixed point & 10/6/2015 11:00 & 5.7 & 787,000 & 11 & 540.2 & 9.877 & 1.123 & 0.568 \\
\hline Fixed point & 10/6/2015 11:12 & 7.3 & 778,000 & 15 & 728.2 & 11.94 & 3.057 & 1.23 \\
\hline Fixed point & $10 / 6 / 201511: 30$ & 8.4 & 818,000 & 15 & 765.6 & 13.36 & 1.636 & 0.817 \\
\hline Fixed point & 10/6/2015 11:42 & 9.7 & 816,000 & 16 & 814.7 & 15.04 & 0.958 & 0.511 \\
\hline Fixed point & 10/6/2015 12:00 & 10 & 857,000 & 20 & 1070 & 15.43 & 4.571 & 2.266 \\
\hline Fixed point & $10 / 6 / 201512: 30$ & 12 & 844,000 & 12 & 632 & 18.01 & -6.012 & -2.266 \\
\hline Fixed point & $10 / 6 / 201512: 36$ & 7.7 & 847,000 & 12 & 634.2 & 12.46 & -0.460 & -0.197 \\
\hline Fixed point & 10/6/2015 13:00 & 6 & 886,000 & 10 & 552.9 & 10.26 & -0.265 & -0.049 \\
\hline Fixed point & $10 / 6 / 201513: 30$ & 4.6 & 936,000 & 7 & 408.8 & 8.457 & -1.457 & -0.817 \\
\hline Fixed point & 10/6/2015 14:00 & 4.6 & 945,400 & 5 & 295 & 8.457 & -3.457 & -1.637 \\
\hline Fixed point & $10 / 6 / 201514: 30$ & 3.8 & 965,000 & 5 & 301.1 & 7.424 & -2.424 & -1.23 \\
\hline Fixed point & $10 / 6 / 201515: 00$ & 4.2 & 986,900 & 4 & 246.3 & 7.941 & -3.941 & -1.863 \\
\hline Fixed point & $5 / 26 / 20166: 30$ & 1.7 & 844,000 & 5 & 263.3 & 4.713 & 0.287 & 0.147 \\
\hline Fixed point & 5/26/2016 7:00 & 1.8 & 846,000 & 8 & 422.3 & 4.842 & 3.158 & 1.342 \\
\hline Fixed point & $5 / 26 / 20167: 30$ & 1.8 & 823,000 & 4 & 205.4 & 4.842 & -0.842 & -0.298 \\
\hline Fixed point & 5/26/2016 8:00 & 1.9 & 846,000 & 4 & 211.2 & 4.971 & -0.971 & -0.456 \\
\hline Fixed point & $5 / 26 / 20168: 42$ & 2.1 & 835,000 & 5 & 260.5 & 5.229 & -0.229 & NA \\
\hline Fixed point & 5/26/2016 9:00 & 2.7 & 874,000 & 9 & 490.8 & 6.004 & 2.996 & 1.132 \\
\hline Fixed point & 5/26/2016 9:30 & 1.7 & 867,000 & 9 & 486.9 & 4.713 & 4.287 & 1.863 \\
\hline Fixed point & $5 / 26 / 201610: 00$ & 1.8 & 890,000 & 6 & 333.2 & 4.842 & 1.158 & 0.626 \\
\hline Fixed point & $5 / 26 / 201610: 30$ & 1.4 & 932,300 & 6 & 349.1 & 4.326 & 1.674 & 0.887 \\
\hline Fixed point & $5 / 26 / 201611: 00$ & 1.4 & 975,500 & 7 & 426.1 & 4.326 & 2.674 & 1.043 \\
\hline
\end{tabular}


Table 1.3. Suspended-sediment concentrations and turbidity rating data for U.S. Geological Survey tide-gaging station 01311875 , Rockaway Inlet at Floyd Bennett Field, New York.-Continued

[Suspended-sediment concentrations (SSC) used for simple linear regression (fig. 11) between fixed-point SSC and turbidity and the 90-percent prediction interval, and the mean equal discharge increment (EDI) SSC data. mm/dd/yyyy hh:mm:ss, month/date, year, hour, minute, second, in Eastern Standard Time; Q, discharge; SSC, suspended-sediment concentration; SSL, suspended-sediment load; NA, not applicable]

\begin{tabular}{|c|c|c|c|c|c|c|c|c|}
\hline Sample type & $\begin{array}{l}\text { Date and time } \\
\text { (mm/dd/yyyy } \\
\text { hh:mm:ss) }\end{array}$ & $\begin{array}{l}\text { Turbidity } \\
\text { (formazin } \\
\text { nephelomet- } \\
\text { ric units) }\end{array}$ & $\begin{array}{c}0 \\
\text { (cubic feet } \\
\text { per second) }\end{array}$ & $\begin{array}{c}\text { SSC } \\
\text { (milli- } \\
\text { grams per } \\
\text { liter) }\end{array}$ & $\begin{array}{c}\text { SSL } \\
\text { (pounds } \\
\text { per } \\
\text { second) }\end{array}$ & $\begin{array}{l}\text { Regression- } \\
\text { computed } \\
\text { SSC } \\
\text { (milligrams } \\
\text { per liter) }\end{array}$ & $\begin{array}{l}\text { Residual } \\
\text { SSC }\end{array}$ & $\begin{array}{c}\text { Normal } \\
\text { quantiles }\end{array}$ \\
\hline Fixed point & 5/26/2016 11:30 & 2 & $1,051,100$ & 5 & 327.9 & 5.1 & -0.100 & 0.049 \\
\hline Fixed point & 5/26/2016 12:00 & 2 & $1,104,000$ & 5 & 344.4 & 5.1 & -0.100 & 0.098 \\
\hline Fixed point & $5 / 26 / 201612: 30$ & 1.1 & $1,182,000$ & 3 & 221.3 & 3.938 & -0.938 & -0.402 \\
\hline Fixed point & 5/26/2016 13:00 & 1.3 & $1,225,000$ & 5 & 382.2 & 4.196 & 0.804 & 0.350 \\
\hline Fixed point & $5 / 26 / 201613: 54$ & 1.3 & $1,175,000$ & 5 & 366.6 & 4.196 & 0.804 & 0.402 \\
\hline Fixed point & $5 / 26 / 201614: 30$ & 1.8 & $1,150,000$ & 2 & 143.5 & 4.842 & -2.842 & -1.342 \\
\hline Fixed point & 5/26/2016 15:00 & 1.3 & $1,124,000$ & 2 & 140.3 & 4.196 & -2.196 & -1.132 \\
\hline Fixed point & $5 / 26 / 201615: 30$ & 1.3 & $1,116,000$ & 3 & 208.9 & 4.196 & -1.196 & -0.687 \\
\hline Fixed point & $5 / 26 / 201616: 00$ & 1.3 & $1,094,500$ & 5 & 341.5 & 4.196 & 0.804 & 0.456 \\
\hline Fixed point & $5 / 26 / 201616: 30$ & 1.3 & $1,041,000$ & 2 & 129.9 & 4.196 & -2.196 & -1.043 \\
\hline Fixed point & 5/26/2016 17:00 & 0.8 & 980,500 & 5 & 305.9 & 3.551 & 1.449 & 0.687 \\
\hline Fixed point & $5 / 26 / 201617: 30$ & 1.5 & 937,600 & 4 & 234 & 4.455 & -0.455 & -0.147 \\
\hline Fixed point & 5/26/2016 18:00 & 1.6 & 867,000 & 5 & 270.5 & 4.584 & 0.416 & 0.197 \\
\hline Fixed point & $5 / 26 / 201618: 30$ & 1.5 & 835,000 & 6 & 312.6 & 4.455 & 1.545 & 0.750 \\
\hline Equal discharge increment & 4/18/2015 9:30 & 1.4 & NA & 4.4 & NA & NA & NA & NA \\
\hline Equal discharge increment & 4/18/2015 10:10 & 1.3 & NA & 4.2 & NA & NA & NA & NA \\
\hline Equal discharge increment & 4/18/2015 16:00 & 2.3 & NA & 6.8 & NA & NA & NA & NA \\
\hline Equal discharge increment & 4/18/2015 16:05 & 2.4 & NA & 6.0 & NA & NA & NA & NA \\
\hline Equal discharge increment & 4/13/2016 15:12 & 2 & NA & 6.0 & NA & NA & NA & NA \\
\hline Equal discharge increment & 4/13/2016 15:54 & 1.8 & NA & 6.2 & NA & NA & NA & NA \\
\hline Equal discharge increment & 4/14/2016 10:54 & 2.1 & NA & 4.6 & NA & NA & NA & NA \\
\hline Equal discharge increment & 4/14/2016 11:24 & 2.2 & NA & 6.4 & NA & NA & NA & NA \\
\hline
\end{tabular}



For more information about this report, contact: Director, New York Water Science Center

U.S. Geological Survey

425 Jordan Road

Troy, NY 12180-8349

dc_ny@usgs.gov

(518) 285-5602

or visit our website at https://www.usgs.gov/centers/ny-water

Publishing support provided by the Pembroke Publishing Service Center 
